(RESEARCH ARTICLE)

\title{
Molecular docking studies of 1, 3, 4 oxadiazoles Derivatives as anti-convulsive agents
}

\author{
Sachin Jangra *, Sachin Kumar and Manjusha Choudhary \\ Institute of Pharmaceutical Sciences, Kurukshetra University, Kurukshetra-136118, Haryana, India.
}

Publication history: Received on 12 October 2020; revised on 22 October 2020; accepted on 24 October 2020

Article DOI: https://doi.org/10.30574/wjarr.2020.8.1.0381

\begin{abstract}
Molecular docking is a computational technique that places a small molecule (ligand) in the binding site of its macromolecular target (receptor) and estimates its binding affinity. The present study attempted the high throughput in-silico screening of 65 compounds docked with the GABAA receptor (PDB ID: 4COF) using Molegro virtual docker (6.0). Out of these 65 compounds, 17 compounds showed very good mol dock score in ranging between -66.344 \& -102.653 . Ethosuximide and Carbamazepine drugs was used as a standard drug which showed mol dock score $-50.6357 \&-$ 58.5047 respectively. Most of test compounds demonstrated excellent number of hydrogen bond interactions viz compounds $33,38,39,45,47,53,54,59,61,62,63,64 \& 65$ which showed 7 to 11 number of hydrogen bond interactions as compared to standard drug interactions values $6 \& 5$ respectively and also showed the interaction with same amino acids Glu52, Ser51and Val53 and some other amino acids Asn54, Thr58 and Thr133 also showed very acceptable bond length less than 3.91A. The obtained results indicated that all studied ligands have similar position and orientation inside the putative binding site of GABAA receptor (PDB ID: 4COF) which reveals a large space bounded by a membranebinding domain which serves as an entry channel for substrate to the active site. In addition, the affinity of any small molecule can be considered as a unique tool in the field of drug design and offer prospective in future research to develop a potent anticonvulsant agent.
\end{abstract}

Keywords: Anti-convulsant activity; Oxadiazoles; In-silico; Docking; GABA; PDB.

\section{Introduction}

Traditional approaches to discovering novel therapeutic medicine were extremely high ticket, more time consuming and perhaps less economical. To overcome drawbacks of traditional strategies, simpler and logical approaches are introduced that deem virtual screening, supported the provision of structural information. The methods of virtual screening are often classified as structure based and ligand-based drug design methodology. The structure-based drug approach describes molecular tying up whereas ligand-based strategies addresses quantitative structure activity relationship (QSAR) and pharmacophore modeling [1]. The molecular docking technique determines interaction between substance and target molecule. It predicts binding affinity of molecules to create a stable complex with supermolecule by finding most well-liked orientation of minimum free energy [2]. Broadly two basic methods are employed in molecular docking i.e. Shape complementarity and Simulation.

\footnotetext{
* Corresponding author: Sachin Jangra

Institute of Pharmaceutical Sciences, Kurukshetra University, Kurukshetra-136118,Haryana. 


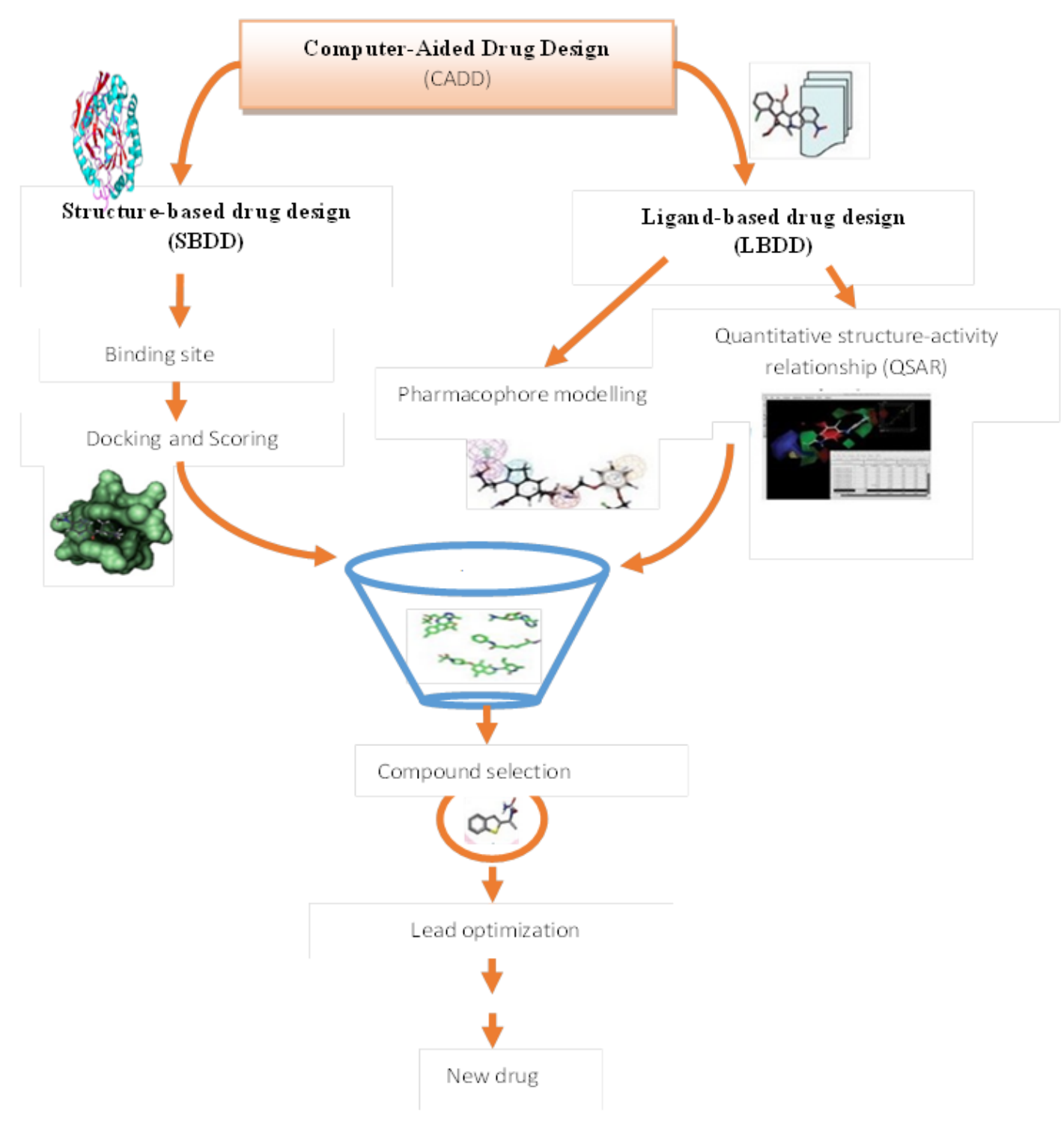

Figure 1 Computer-aided drug design

The Molecular docking is classified into three categories:

- Induced work docking: In this method, each matter and receptor are versatile. The matter binds flexibly at the site of receptor to maximize bonding forces between them and implementing the conception of complementarity between macromolecule and matter.

- Lock and key docking: In this method both matter and receptor are rigid and show tight binding [3]. It defines the essential conception of three-dimensional complementarity.

- Ensemble docking: This approach explains flexibility and complexity of conformational states of proteins. Multiple super molecule structures used as associate degree ensemble for docking with matter $[4,5]$. 


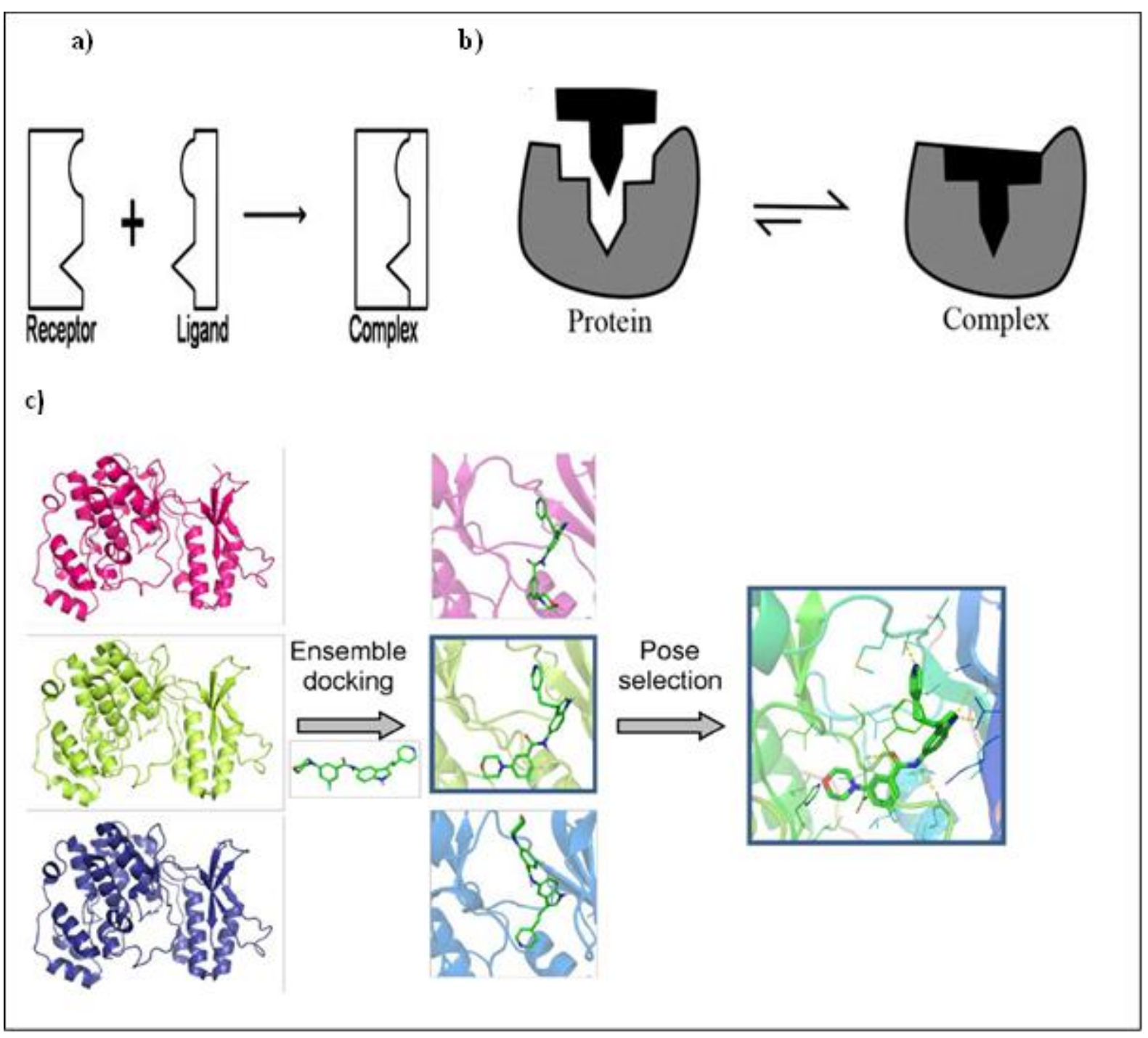

Figure 2 Different technique for Molecular docking: a) Induced work docking b) Lock and key docking c) Ensemble docking

Epilepsy is a common and usually destructive disorder, identified by the abnormal and periodic discharge of neurons within brain. It is also known as chronic neurological disorder identified by the unpredictable and periodic occurrence of seizures. Brain is unable to read the message and results in seizures, loss of consciousness, jerking in body muscle, contraction in muscle etc ${ }^{[6-8]}$. According to recent studies in world health organization, approximately 2.4 million annual cases and about 50 million people are affected with epilepsy in worldwide ${ }^{[9-10]}$. It is noncommunicable disorder of brain \& evaluated that $70 \%$ of patients can live seizure free if properly diagnosed and treated. Recent study showed that frequency of active epilepsy is estimated 6.38 per 1000 person and prevalence rate was 61.44 per 100,000 persons/years [11-12]. Around about $1 \%$ of population is affected from the epilepsy [13]. At present about 40 forms of epilepsy are specified [14]. Epilepsy cause substantial impact on social, health and quality of life of patients as compared to healthy people [15-17].

Heterocyclic compounds play a crucial role within the diligent effort to develop new anti-convulsant agents. Various artificial approaches supported chemical modification have been undertaken with associate aim to boost the protection profile of anticonvulsant activity.

Compounds containing heterocyclic system, with $\mathrm{N}$ and $\mathrm{O}$ as hetero-atoms possess a broad range of biological activity [18]. Among numerous consolidated and free hetero atomic rings gift, oxadiazole ring system provides pervasive options of solely pharmaceutical product and additionally stated as furodiazoles. Oxadiazole ring has been classified into four totally different teams as 1:2:3-oxadiazole, 1:2:5oxadiazole, 1:2:4-oxadiazole, 1:3:4-oxadiazole [19]. 
<smiles>c1conn1</smiles>

1,2,4-oxadiazole<smiles>c1cnon1</smiles>

1,2,5-oxadiazole<smiles>c1ncon1</smiles>

1,2,4-oxadiazole<smiles>c1nnco1</smiles>

1,3,4-oxadiazole

Figure 3 Basic structures of Oxadiazole

The first synthesis of 1,2,4-oxadiazoles, originally named as furodiazoles, was achieved a hundred twenty-five years past by Tiemann and Krüger. Since then, till early 1960's many articles published oxadiazoles and within the next decade 1, 2, 4-oxadiazoles gained abundant interest because of their tendency to bear molecular rearrangements. Oxadiazoles are usually remarked because of bio-ester for amides and esters and show improved pharmacokinetic and In vivo performance and because of hyperbolic stability of the ring. This property makes this molecule a vital moiety for the pharmaceutical business. As a result, oxadiazoles are usually employed in varied drug discovery programs as medication agents, anti-tumor agents, and $\mathrm{H} 3$ receptor antagonists as potent inhibitors of MIF biological operate, and bell-tryptase inhibitors. Oxadiazole ring additionally shows a large spectrum of activity against gram positive and gramnegative microorganism ${ }^{[20]}$.

1,3,4-oxadiazole ring has been observed to be a flexible pharmacophore with an extensive variety of valuable organic exercises for example hostile to inflammatory ${ }^{[21-22]}$ against tubercular ${ }^{[23]}$ and against cancer [24].

As oxadiazole is very potent moiety and significant scope for development of new drugs. So molecular docking is used as a tool for prediction of MolDock score of different compounds which shows the ligand-protein interaction, so by this we will be able to find the significant anti-convulsant activity by molecular docking.

\section{The targets of anticonvulsant drug discovery}

In-silico docking study of 65 compounds gave us an idea about the derivatives responsible for anti-epileptic activity. The obtained results indicated that all studied ligands have similar position and orientation inside the putative binding site of $\mathrm{GABA}_{\mathrm{A}}$ receptor (PDB ID: 4COF) which reveals a large space bounded by a membrane-binding domain which serves as an entry channel for substrate to the active site. In addition, the affinity of any small molecule can be considered as a unique tool in the field of drug design. There is a relationship between the affinity of organic molecules and the free energy of binding. This relationship can contribute in prediction and interpretation of the activity of the organic compounds toward the specific target protein may be the possible mechanism by which derivatives displayed their anti-epileptic activity as on this protein constituent are most appropriately docked.

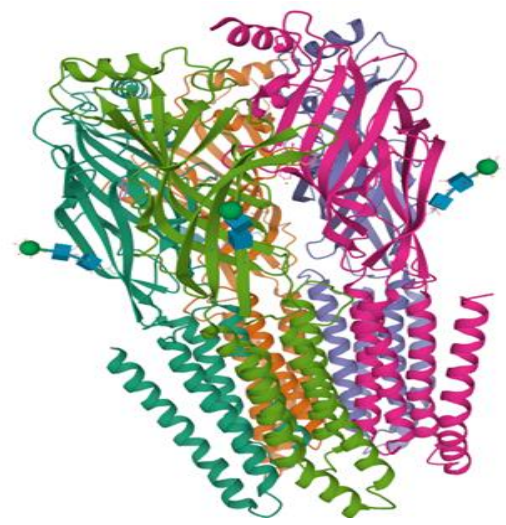

Figure 4 3D view of PDB: 4COF 


\section{Methodology}

Docking may be a technique to figure out a substance's possible binding modes to a receptor site. Docking studies has been performed with a group of theoretic oxadiazole derivatives exploitation Molegro virtual docker 6.0 on COX I (PDB ID 4COF). The X-ray structures of that were accessed from the supermolecule knowledge bank (PDB). The basic structure of analogues is shown in Table 1.

\subsection{The methodology can be divided in to following steps}

- Importing a protein file, ligand file and preparation of ligands.

- $\quad$ Protein preparation and detecting cavities of protein molecules.

- Executing a docking set up through docking wizard panel.

- Determination of poses of protein ligand complexes.

- Calculation of MolDock score and hydrogen bond interaction.

\subsubsection{Selection of the compounds and ligand preparation}

The hypothetical compounds were line-up based on literature. The ligand molecules were prepared by using ChemDraw professionals 15.0 and Marvin Sketch and then molecules were converted to 2D and then converted to 3D using build and optimize method and then clean in 3D. The resulting structure will be saved in MDL Molfile (*.mol) format. A single, low energy, 3D structure with correct chirality for each successfully proposed structure will be generated. Then the generated structure was imported in to the workspace of docking software Molegro Virtual Docker. Molecule can be incorporated in to the MVD using MDL ( $\mathrm{sdf} / \mathrm{sd} / \mathrm{mol} / \mathrm{mdl}$ ) file format which contains bonding formation. In this step the preparation of molecules were assigned bonds, bond order and hybridization, charges, explicit hydrogens and flexible torsion in ligands.

\subsubsection{Compound selection}

On the basis of literature data, we selected 65 hyothetical compounds and docking studies were performed using (PDB ID 4COF) for anti-convulsant activity using Molegro Virtual Docker. However, all hypothetical compounds were found to possess moderate results for anti-convulsant activity. But out of sixty-five compounds, 13 compounds (H-bonding: 711) which we selected were found to be possesses best results for anti-convulsant activity. The docking output of 65 compounds is given in table-2.

\subsubsection{Set of hypothetical compounds}

Docking study performed with a set of hypothetical oxadiazole derivatives. The basic moiety of compounds is shown in figure 5. The structure of all 65 compounds are illustrated in Table 1.

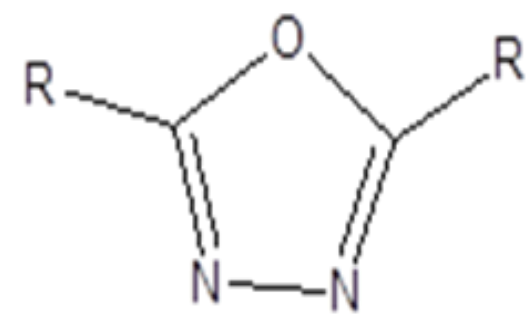

Figure 5 Basic moiety of 1, 3, 4-oxdiazole

\subsubsection{Protein preparation}

In Molegro Virtual Docker the step protein preparation is automatically performed. Docking is a computational method for predicting modes of action of small organic molecules to protein receptors. It makes an image of the active site with interaction points known as grid. It fits the ligand in the binding site of the receptor. Different types of interaction between receptor and ligand Vander Waal's interaction, aromatic interactions are considered to calculate the binding energy. The number of protein receptor (PDB) used in this study are PDB ID: 4COF. The PDB used for docking was produced from RCSB (protein data bank). 


\subsubsection{Ligand docking}

Ligand docking was achieved by generating a number of poses of a ligand with in the active site, and scoring of poses to identify one or more poses that closely approximate the bioactive conformation determined by X-ray crystallography.

Protein (PDB code: 4COF) was downloaded from the protein information Bank. All designed matters and reference ligand, Dilantin were foreign within the work area space of Molegro Virtual Docker, and necessary bonds, bond orders, hybridizations, gas atoms and charges were allotted. Protein ligand tying up studies were allotted supported the idea of crystal structure of protein Pdb: 4COF and matter binding. All solvents molecule, chemical compound and cocrystallized ligands were far away from structures. The parameter elects in the tying up studies were weight unit dock optimizer, variety of runs ten, cavity elect is user outline. The choice of the ligands from the docking wizard was done on the basis of the marking perform (Mol Dock score and hydrogen bond interaction).

The Mol dock scoring function (Mol Dock Score), E-score is defined by the following energy terms:

E score $=\mathrm{E}$ inter $+\mathrm{E}$ intra

Where $\mathrm{E}$ intra is the inter energy of the ligand; $\mathrm{E}$ inter is the ligand -protein interaction energy.

Table 1 Structure of hypothetical compounds

COMPOUND NAME


World Journal of Advanced Research and Reviews, 2020, 08(01), 151-179

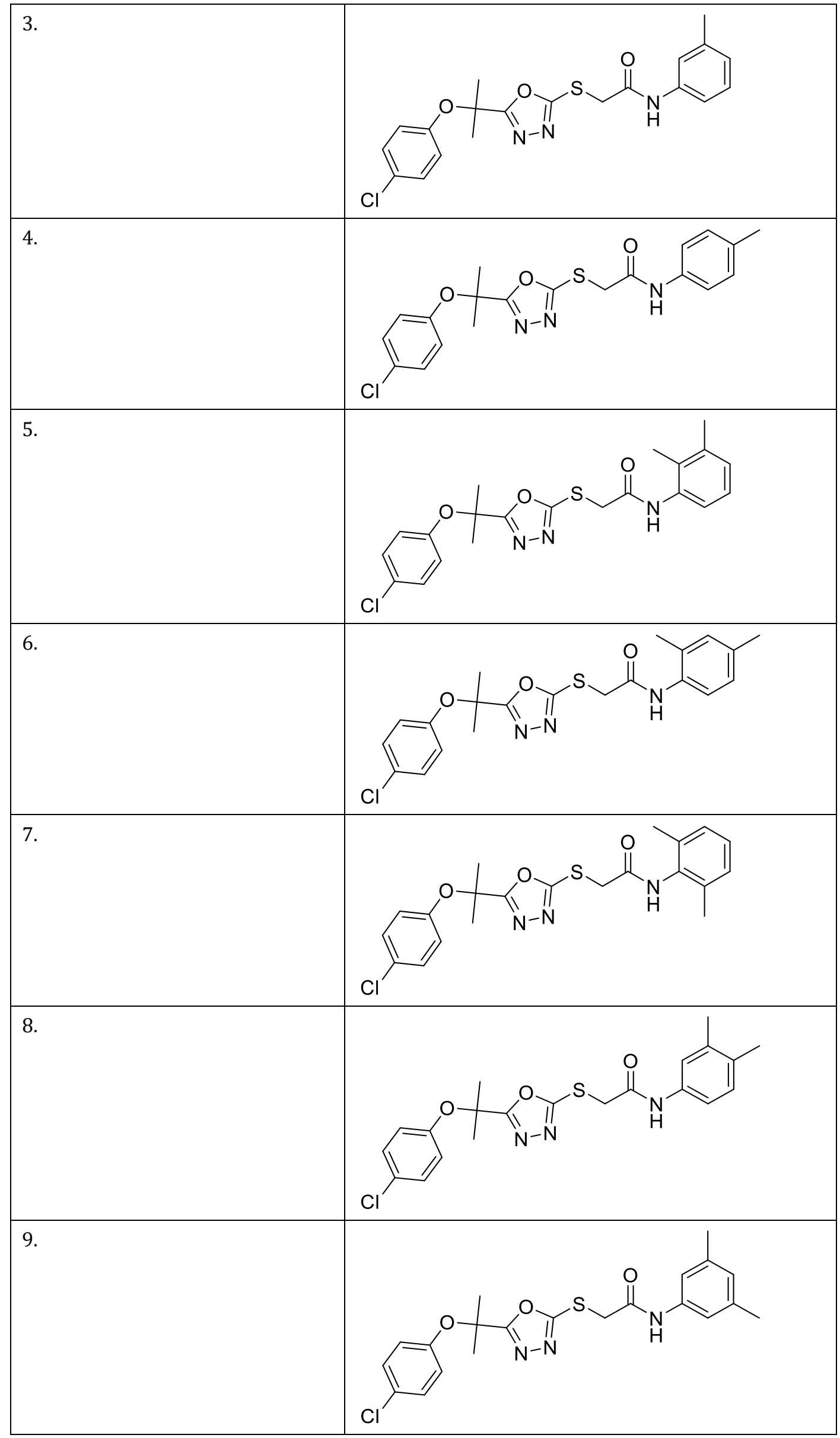


World Journal of Advanced Research and Reviews, 2020, 08(01), 151-179

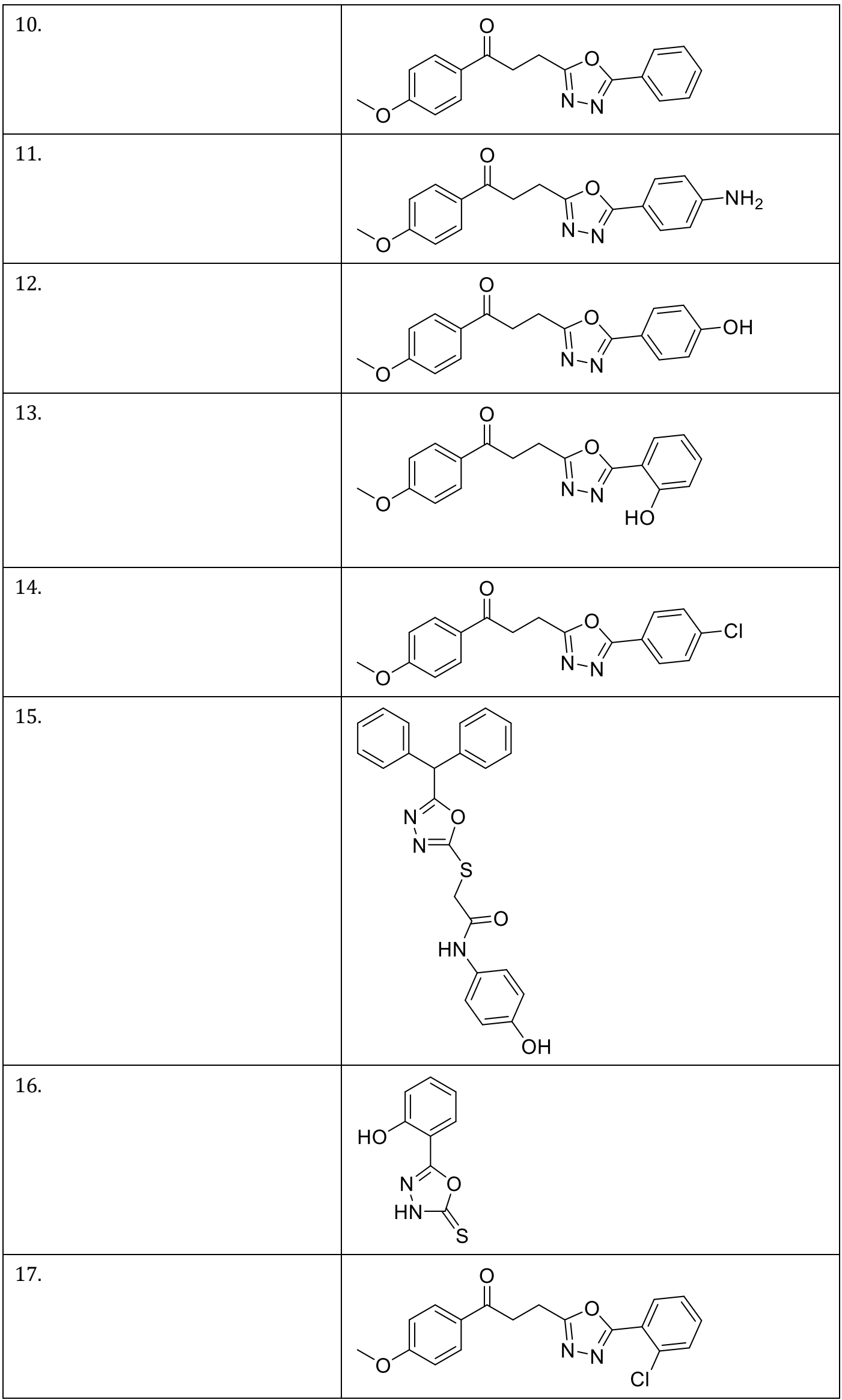


World Journal of Advanced Research and Reviews, 2020, 08(01), 151-179

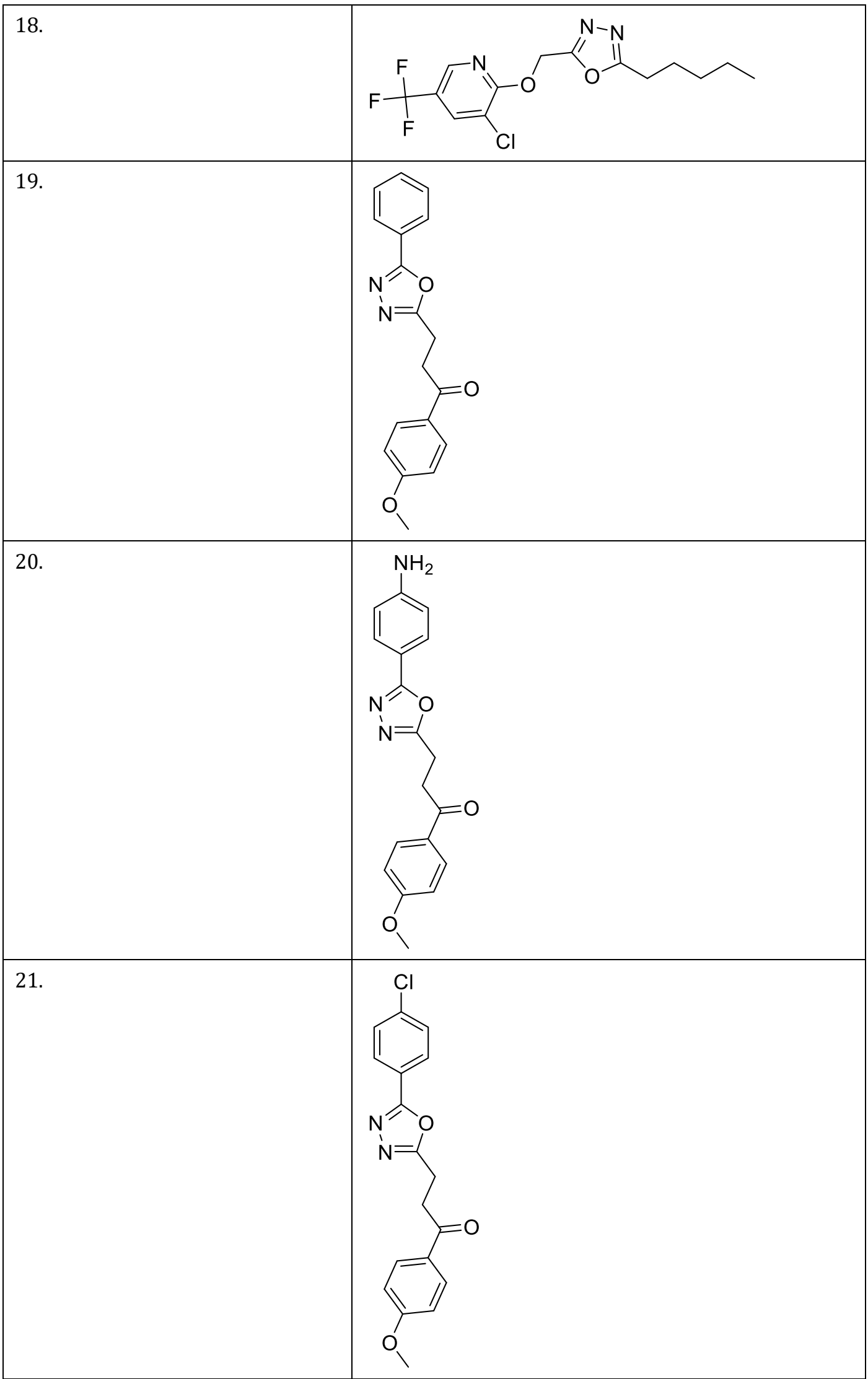


World Journal of Advanced Research and Reviews, 2020, 08(01), 151-179

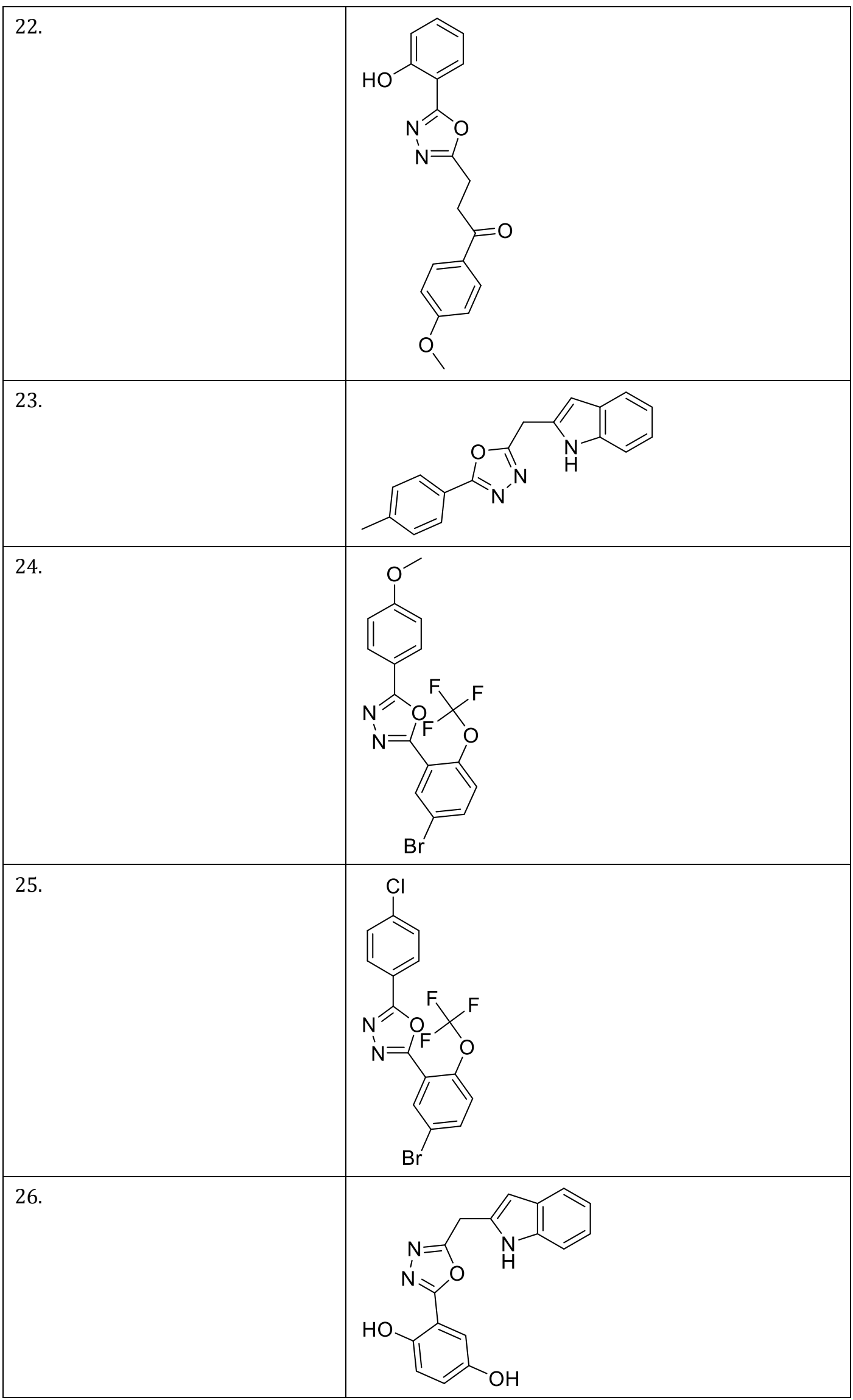


World Journal of Advanced Research and Reviews, 2020, 08(01), 151-179

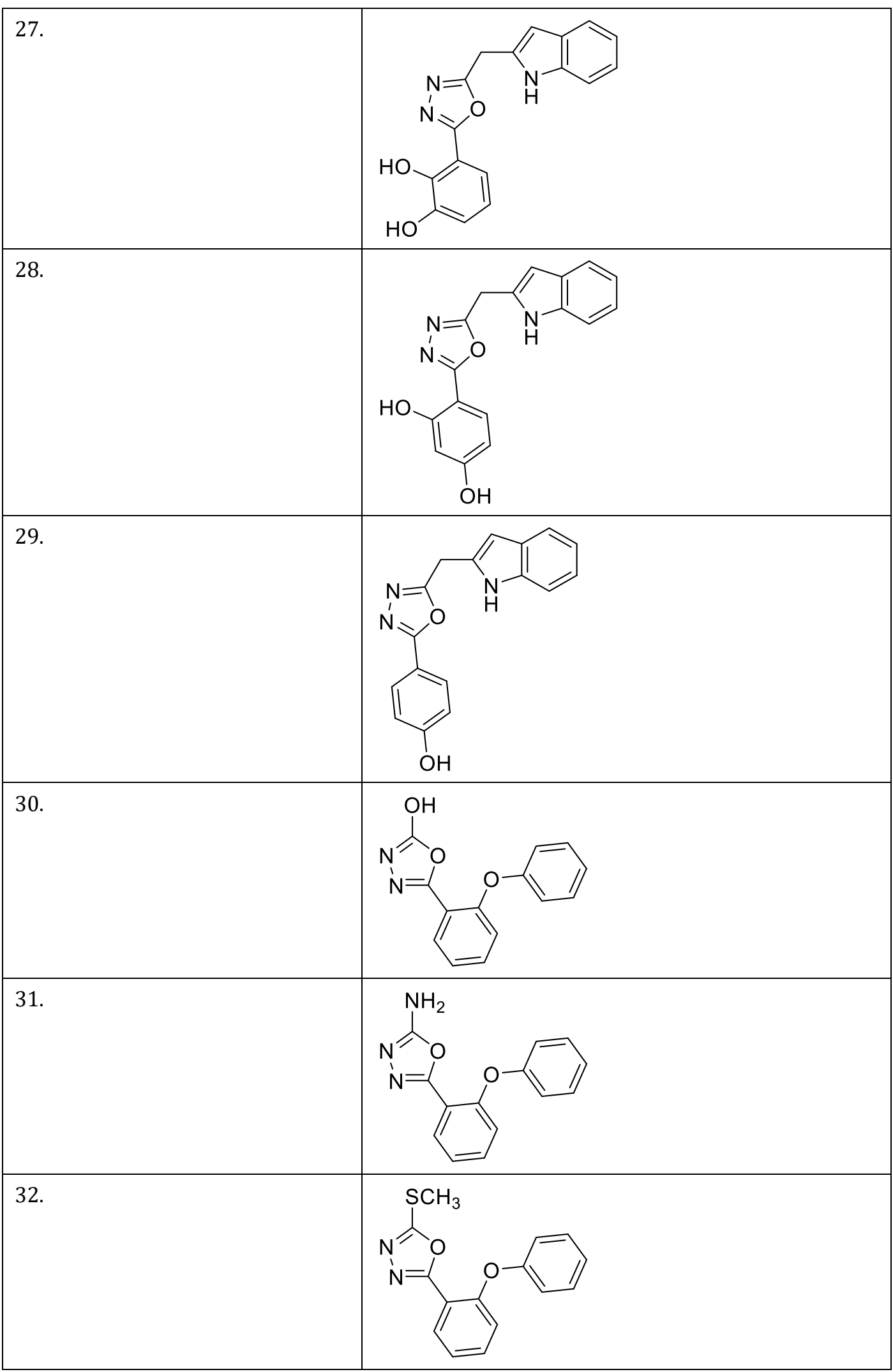


World Journal of Advanced Research and Reviews, 2020, 08(01), 151-179

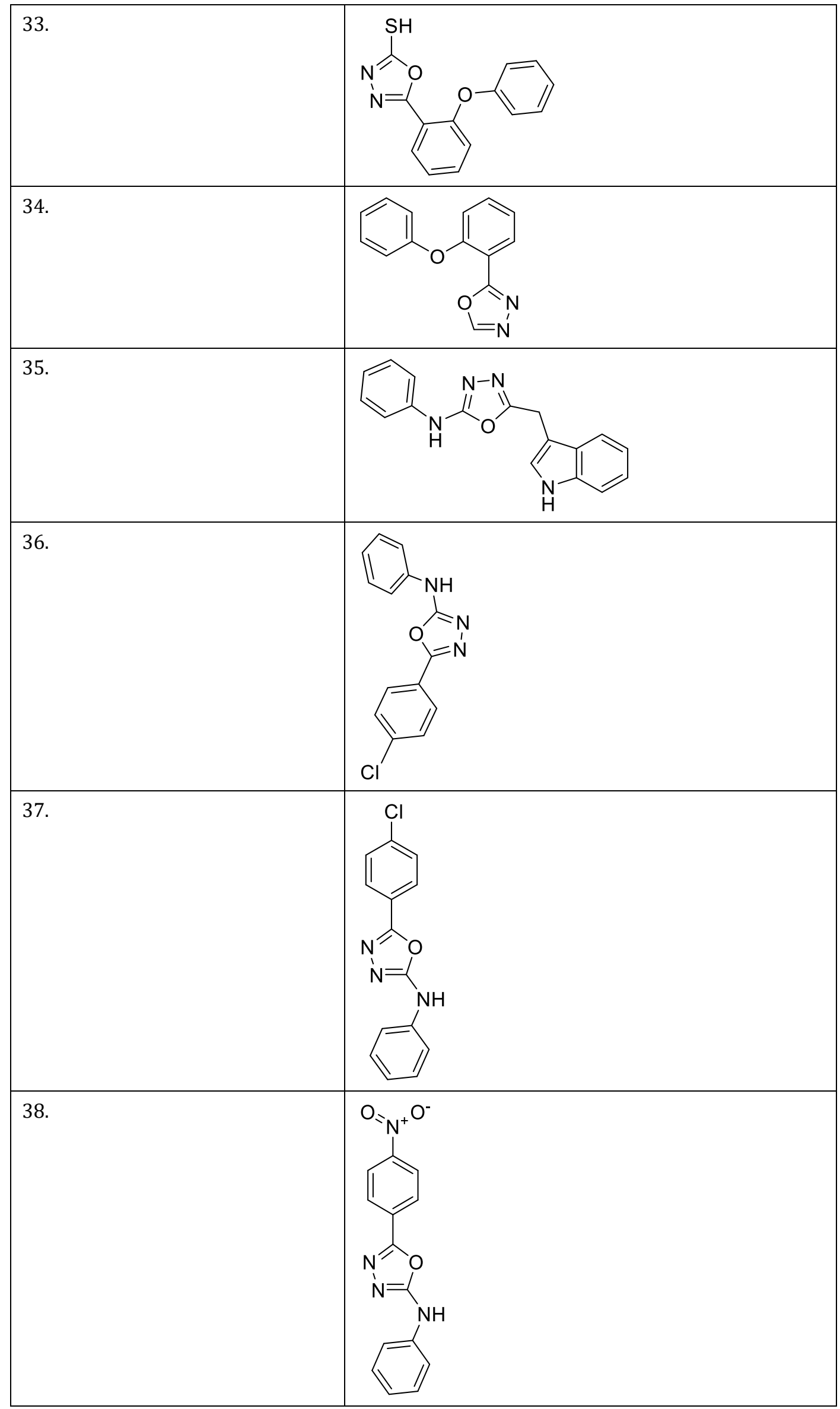


World Journal of Advanced Research and Reviews, 2020, 08(01), 151-179

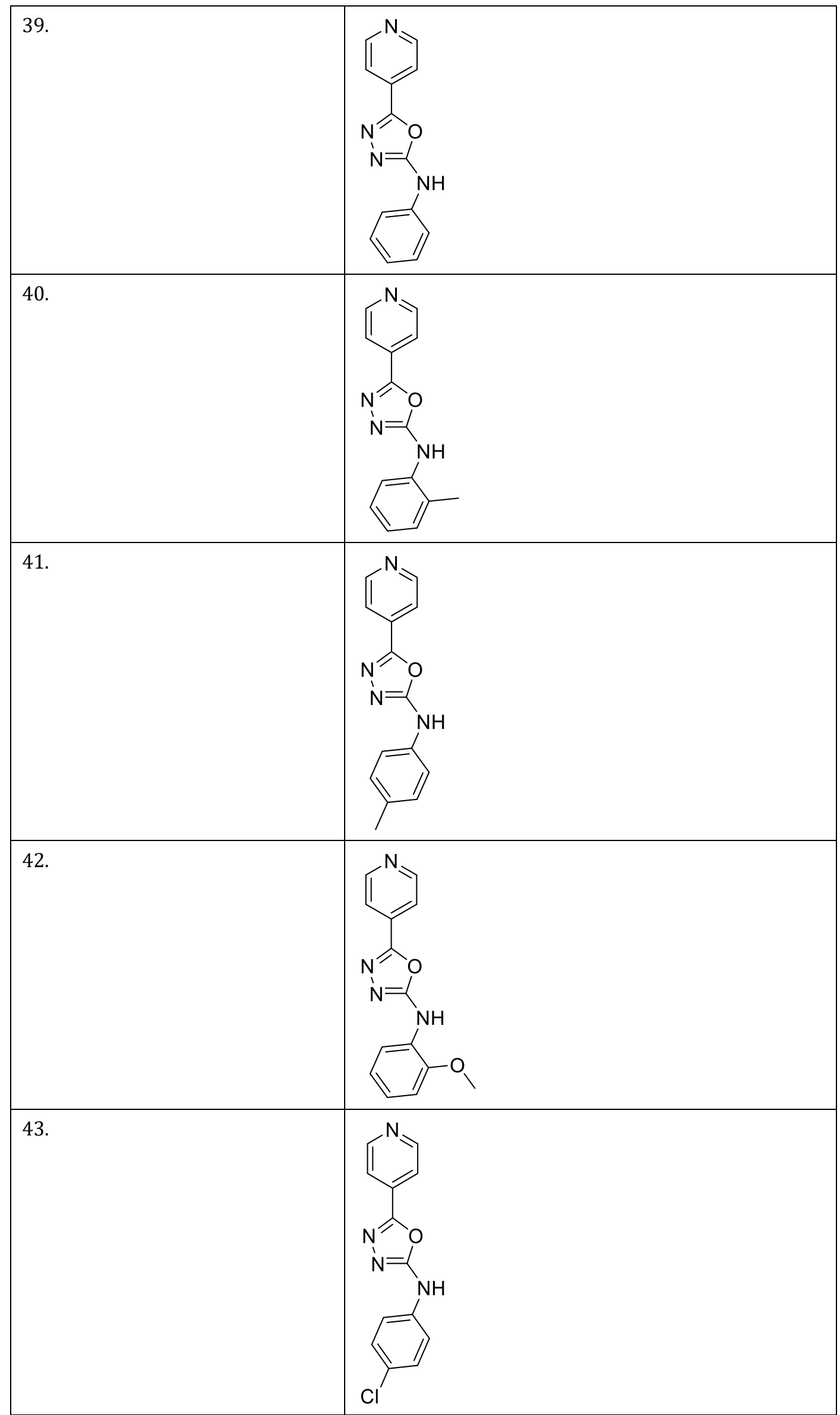


World Journal of Advanced Research and Reviews, 2020, 08(01), 151-179

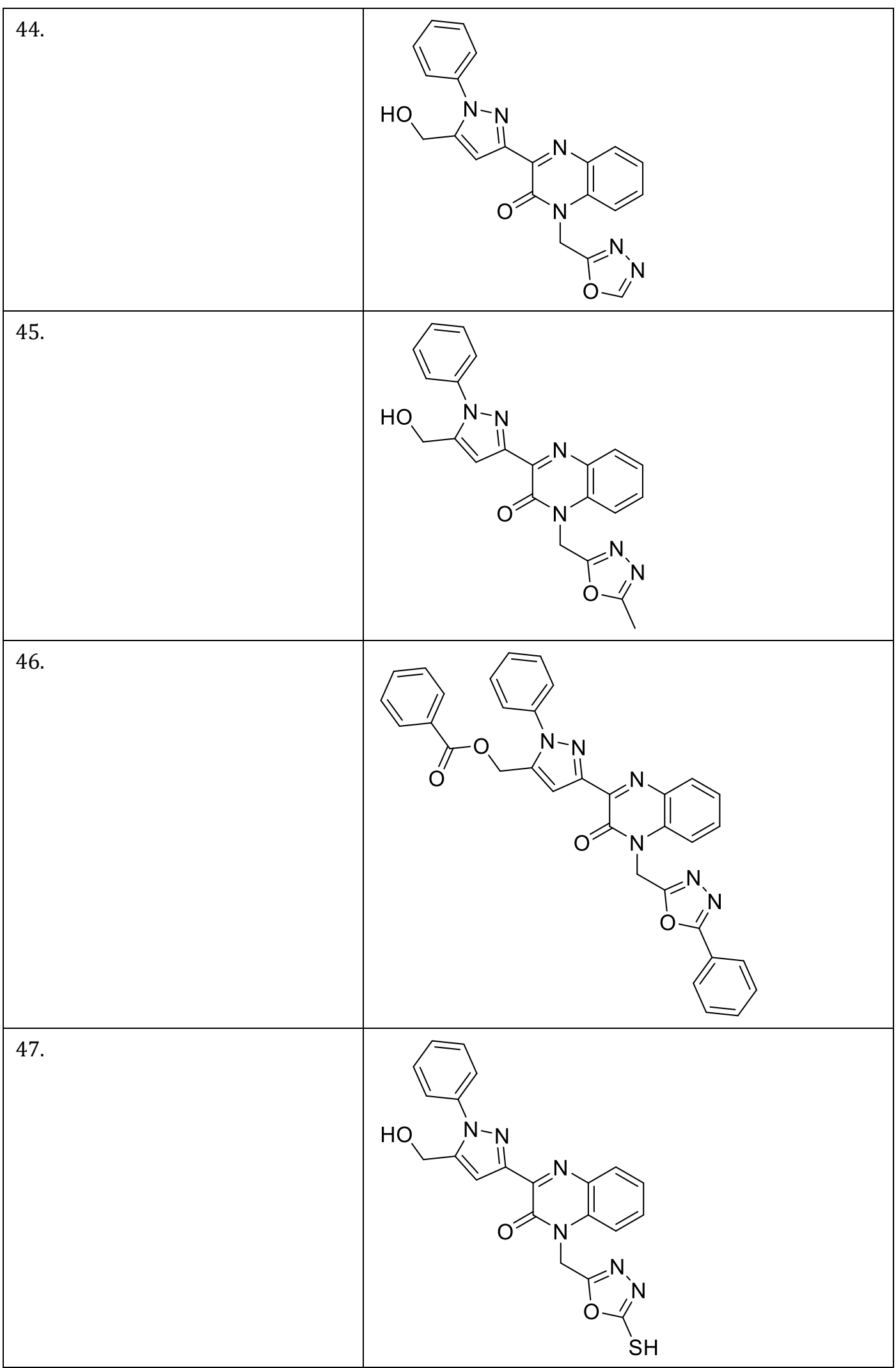


World Journal of Advanced Research and Reviews, 2020, 08(01), 151-179

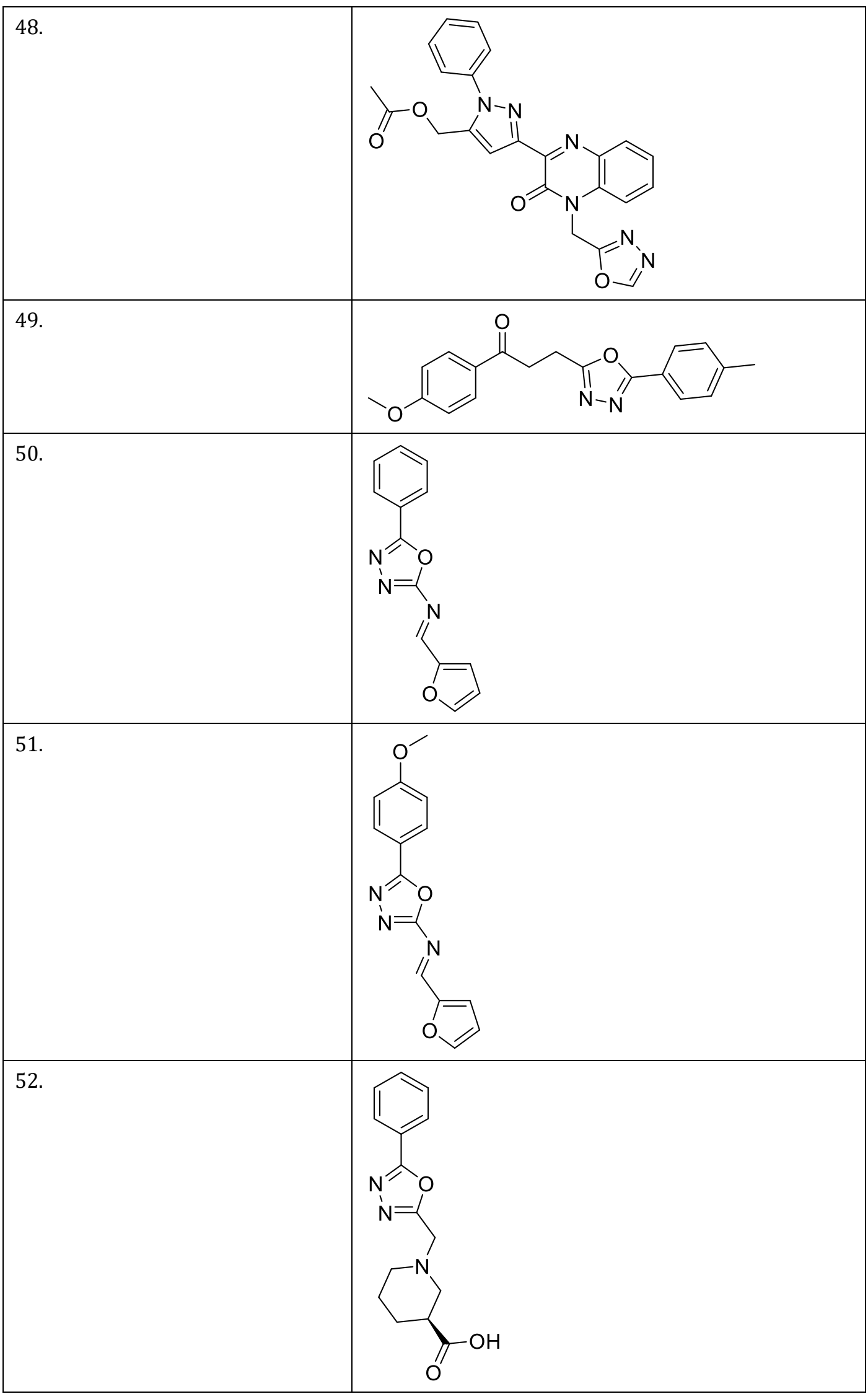


World Journal of Advanced Research and Reviews, 2020, 08(01), 151-179

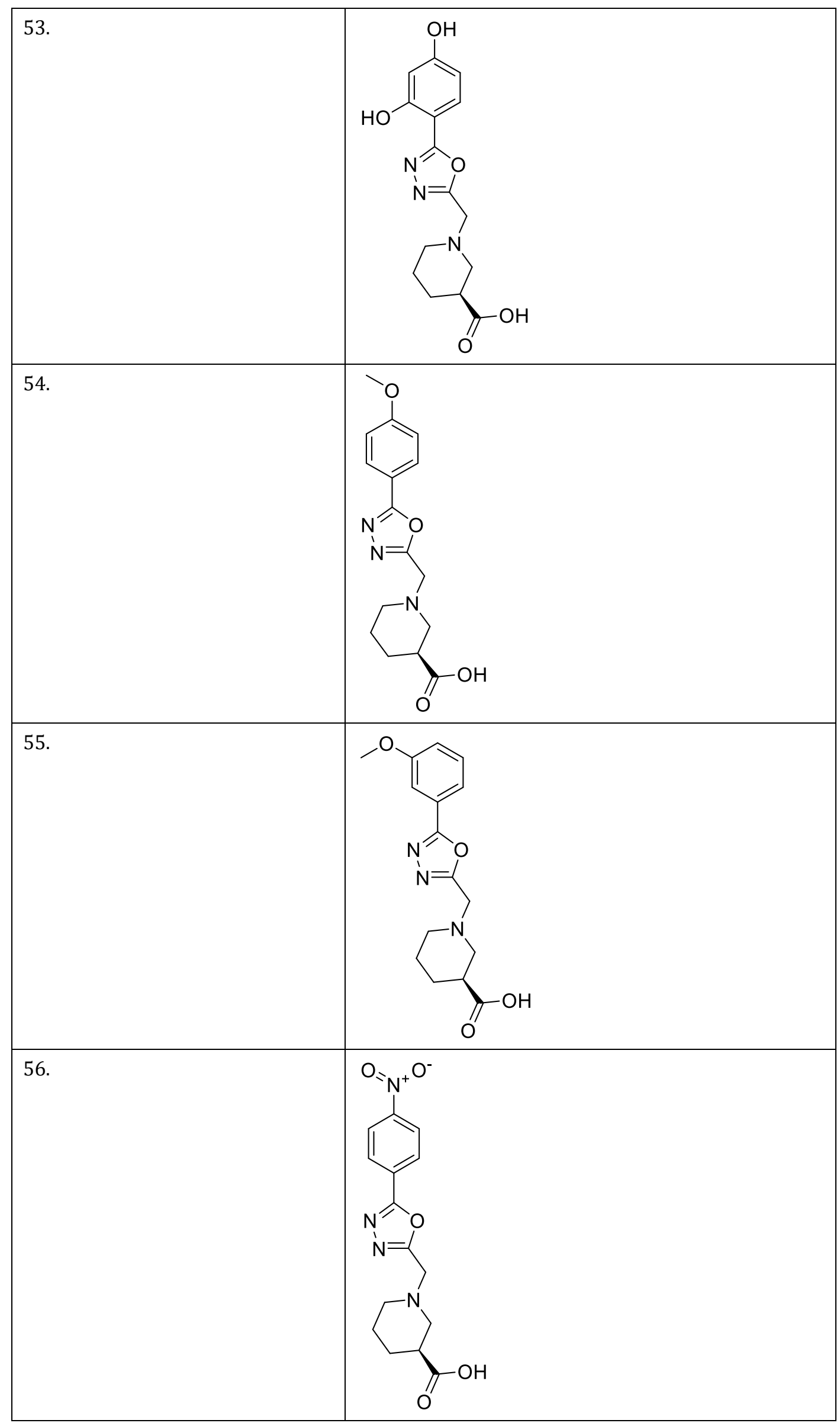


World Journal of Advanced Research and Reviews, 2020, 08(01), 151-179

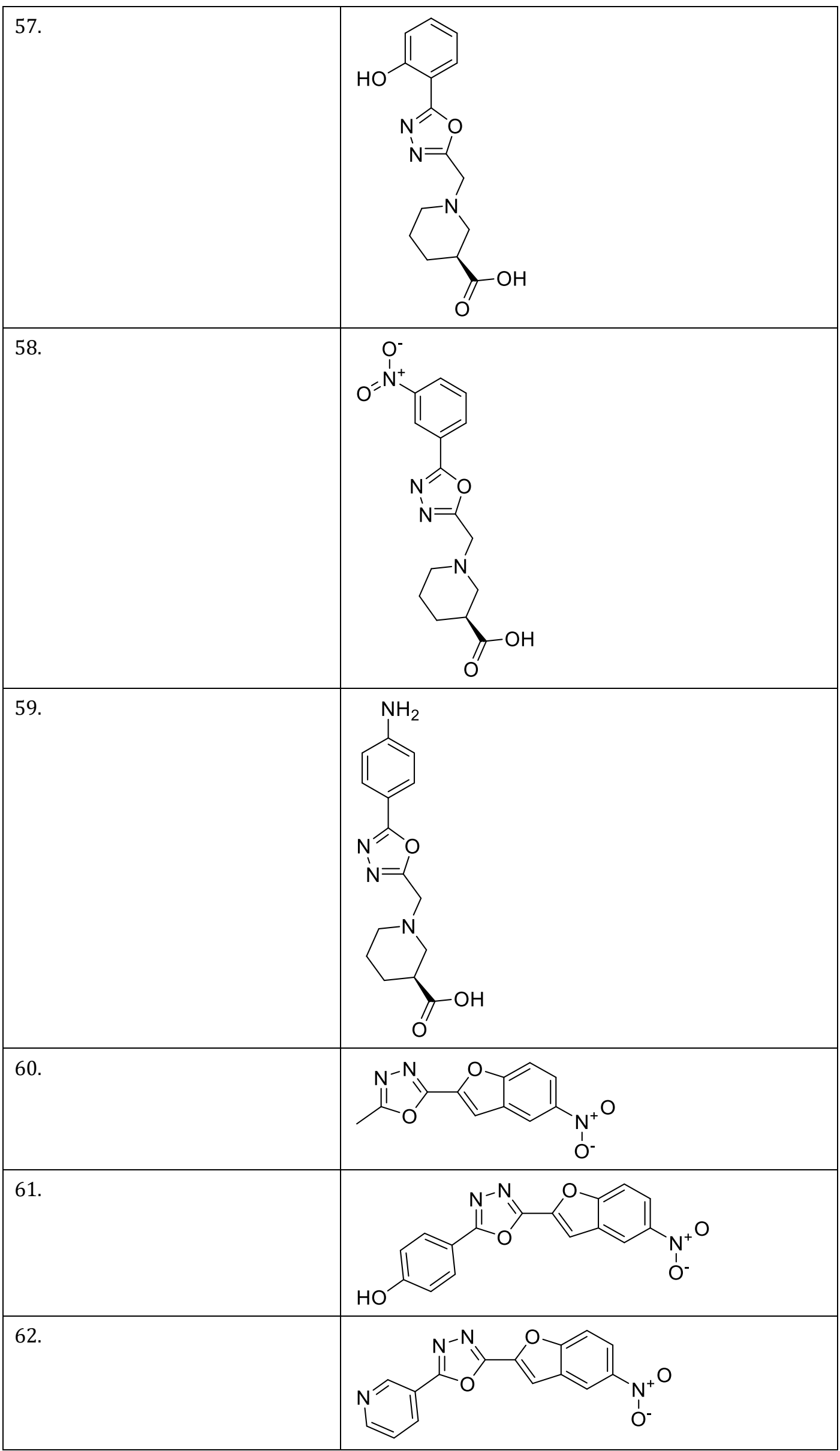




65.26.

\section{Results and discussion}

The significant outputs of molecular docking are associated with interaction site of enzyme with the ligand. The interaction of standard and test compounds were compared and the outcome has been summarized in tabular form as mol dock score, rerank score, docking score and number of hydrogen bonding. The docking energies of the ligands found negative that shows the stable binding interaction between the receptor and the ligands.

Here, we studied the docking of 65 compounds using PDB(4COF) with Ethosuximide and Carbamazepine as standard compound. Out of these 65 compounds, compounds 33, 38, 39, 45, 47, 48, 53, 54, 55, 58, 59, 60, 61, 62, 63, 64 and 65 were found potent result for the anticonvulsant activity. The standard drug Ethosuximide and Carbamazepine showed H-bond interaction in some common amino acids that are Glu52, Ser51and Val53 with different bond length(figure-6). In these sixty-five compounds, eighteen compounds $33,38,39,45,47,48,49,53,54,55,58,59,60,61,62,63,64$ and 65 were found to be the potent having maximum hydrogen bonding or interaction with a good Moldock score and also showed the interaction with same amino acids Glu52, Ser51and Val53. Some other amino acids found common among these compounds is Asn54, Thr58 and Thr133 and showed very acceptable bond length (less than 3.91Å).

The docking output of 65 compounds along with standard compounds are presented in Table -2 with details of interacting amino acids, bond length, no. of hydrogen bond interaction, rerank score and Moldock score.

Table 2 Ligand-receptor interaction data of 1,3,4-0xadiazoles on PDB ID: 4COF using Molegro software

\begin{tabular}{|l|l|l|l|l|}
\hline Sr. No. & $\begin{array}{l}\text { Interaction of } \\
\text { amino acid with } \\
\text { H-bond (A)) } \\
\text { having shortest } \\
\text { bond length }\end{array}$ & $\begin{array}{l}\text { Number of } \\
\text { hydrogen bond } \\
\text { interactions }\end{array}$ & Mol dock score & Rerank score \\
\hline Ethosuximide & $\begin{array}{l}\text { Lys274B(3.10) } \\
\text { Gln185A(3.25) } \\
\text { Ser51A(3.13) } \\
\text { Glu52A(2.45) } \\
\text { Glu52A(2.82) } \\
\text { Val53A(3.10) }\end{array}$ & 6 & -50.6357 & -42.4839 \\
\hline Carabamazepine & $\begin{array}{l}\text { Thr271E(3.31) } \\
\text { Val53E(3.10) } \\
\text { Ser51E(3.19) }\end{array}$ & 5 & -58.5047 & -53.9331 \\
\hline
\end{tabular}




\begin{tabular}{|c|c|c|c|c|}
\hline & $\begin{array}{l}\text { Glu52E(3.15) } \\
\text { Glu52E(2.87) }\end{array}$ & & & \\
\hline 1. & $\begin{array}{l}\text { Lys274A(3.10) } \\
\text { Tyr220E(3.06) }\end{array}$ & 02 & -95.8228 & -59.7865 \\
\hline 2. & $\begin{array}{l}\text { Ser51D(3.11) } \\
\text { Lys274E(3.43) } \\
\text { Lys274E(3.10) } \\
\text { Lys274E(3.50) }\end{array}$ & 04 & -85.6591 & -58.0514 \\
\hline 3. & Glu270E(2.78) & 01 & -97.1901 & -73.912 \\
\hline 4. & $\begin{array}{l}\text { Tyr220E(2.98) } \\
\text { Leu272A(3.58) }\end{array}$ & 02 & -92.4044 & -69.3391 \\
\hline 5. & Asn54E(2.96) & 01 & -91.4694 & -58.5197 \\
\hline 6. & Lys274A(2.50) & 01 & -101.697 & -71.1179 \\
\hline 7. & Lys274A(3.11) & 01 & -98.3586 & -65.0526 \\
\hline 8. & Lys274A(3.10) & 01 & -94.1804 & -72.2179 \\
\hline 9. & Asn54A(3.04) & 01 & -102.346 & -63.6321 \\
\hline 10. & $\begin{array}{l}\text { Lys274A(3.07) } \\
\text { Lys274A(2.61) } \\
\text { Lys274A(3.10) } \\
\text { Val50E(2.69) }\end{array}$ & 04 & -111.146 & -79.9032 \\
\hline 11. & $\begin{array}{l}\text { Thr133A(3.21) } \\
\text { Lys102A(2.62) } \\
\text { Lys102A(2.66) } \\
\text { Thr133E(3.31) } \\
\text { Thr58E(2.97) }\end{array}$ & 05 & -98.0033 & -59.3164 \\
\hline 12. & $\begin{array}{l}\text { Lys274A(3.14) } \\
\text { Lys274A(2.99) } \\
\text { Lys274A(2.73) } \\
\text { Ser51E(1.65) }\end{array}$ & 04 & -96.5329 & -74.226 \\
\hline 13. & $\begin{array}{l}\text { Glu270E(2.91) } \\
\text { Val53E(3.18) } \\
\text { Glu52E(3.10) } \\
\text { Ser51E(2.94) } \\
\text { Gln185E(3.12) }\end{array}$ & 05 & -89.208 & -65.2274 \\
\hline 14. & $\begin{array}{l}\text { Val50E(2.98) } \\
\text { Lys274A(2.60) } \\
\text { Lys274A(3.37) }\end{array}$ & 03 & -116.542 & -85.8967 \\
\hline 15. & $\begin{array}{l}\text { Thr271E(1.78) } \\
\text { Lys274A(3.25) }\end{array}$ & 02 & -115.841 & -80.932 \\
\hline 16. & $\begin{array}{l}\text { Tyr220E(2.43) } \\
\text { Tyr220E(3.10) } \\
\text { Leu272A(2.85) } \\
\text { Glu270A(2.74) }\end{array}$ & 04 & -72.322 & -54.4905 \\
\hline 17. & Lys274E(2.95) & 04 & -96.5158 & -48.8088 \\
\hline
\end{tabular}




\begin{tabular}{|c|c|c|c|c|}
\hline & $\begin{array}{l}\text { Glu52D(2.77) } \\
\text { Ser51D(3.11) } \\
\text { Val53D(3.05) }\end{array}$ & & & \\
\hline 18. & $\begin{array}{l}\text { Tyr220D(3.42) } \\
\text { Tyr220D(3.07) }\end{array}$ & 02 & -92.3284 & -75.375 \\
\hline 19. & $\mathrm{Gln} 185 \mathrm{E}(2.86)$ & 01 & -109.764 & -84.1751 \\
\hline 20. & $\begin{array}{l}\text { Tyr220E(2.59) } \\
\text { Lys102A(2.75) }\end{array}$ & 02 & -91.4715 & -70.5589 \\
\hline 21. & $\begin{array}{l}\text { Lys12A(3.11) } \\
\text { Lys12A(2.14) }\end{array}$ & 02 & -104.64 & -82.5021 \\
\hline 22. & $\begin{array}{l}\text { Glu52E(3.53) } \\
\text { Ser51E(3.30) }\end{array}$ & 02 & -102.304 & -81.1484 \\
\hline 23. & Lys274A(3.44) & 01 & -102.717 & -82.81 \\
\hline 24. & $\begin{array}{l}\text { Lys102A(3.10) } \\
\text { Thr133A(3.23) } \\
\text { Thr58A(2.78) }\end{array}$ & 03 & -75.2525 & -54.7127 \\
\hline 25. & $\begin{array}{l}\text { Thr133E(2.84) } \\
\text { Thr133E(3.30) } \\
\text { Lys103(3.40) }\end{array}$ & 03 & -70.8493 & -47.6266 \\
\hline 26. & $\begin{array}{l}\text { Glu270A(2.65) } \\
\text { Lys274A(2.72) }\end{array}$ & 02 & -101.677 & -71.4514 \\
\hline 27. & Lys102E(2.60) & 01 & -85.6654 & -53.9046 \\
\hline 28. & $\begin{array}{l}\text { Lys274E(3.19) } \\
\text { Leu272E(2.34) } \\
\text { Asp18D(1.70) }\end{array}$ & 03 & -101.708 & -80.1013 \\
\hline 29. & $\begin{array}{l}\text { Glu270A(2.65) } \\
\text { Lys274A(3.06) } \\
\text { Val50E(3.11) }\end{array}$ & 03 & -101.432 & -56.6811 \\
\hline 30. & $\begin{array}{l}\text { Tyr220E(2.99) } \\
\text { Arg269A(3.47) } \\
\text { Glu270A(3.08) } \\
\text { Tyr220E(2.27) }\end{array}$ & 04 & -73.7494 & -57.4245 \\
\hline 31. & $\begin{array}{l}\text { Leu272A(2.60) } \\
\text { Arg269A(3.48) } \\
\text { Tyr220E(2.92) } \\
\text { Tyr220E(2.22) }\end{array}$ & 04 & -74.32 & -58.0099 \\
\hline 32. & $\begin{array}{l}\text { Gln185E(3.11) } \\
\text { Lys274A(2.80) } \\
\text { Lys274A(2.85) }\end{array}$ & 03 & -83.0779 & -62.2767 \\
\hline 33. & $\begin{array}{l}\text { Asn54A(3.20) } \\
\text { Val53A(2.74) } \\
\text { Val53A(2.68) } \\
\text { Ser51A(3.02) }\end{array}$ & 08 & -73.6727 & -57.4343 \\
\hline
\end{tabular}




\begin{tabular}{|c|c|c|c|c|}
\hline & $\begin{array}{l}\text { Ser51A(2.68) } \\
\text { Glu52A(2.63) } \\
\text { Glu52A(2.89) } \\
\text { Thr271A(1.28) }\end{array}$ & & & \\
\hline 34. & $\begin{array}{l}\text { Gln185E(3.10) } \\
\text { Lys274A(3.15) } \\
\text { Gln185E(2.81) }\end{array}$ & 03 & -67.928 & -39.16665 \\
\hline 35. & $\begin{array}{l}\text { Lys102E(3.00) } \\
\text { Lys102E(3.06) } \\
\text { Lys102E(3.43) } \\
\text { Asn54E(3.21) }\end{array}$ & 04 & -82.0643 & -67.5459 \\
\hline 36. & $\begin{array}{l}\text { Thr271E(3.03) } \\
\text { Lys274A(3.41) } \\
\text { Tyr220E(1.38) }\end{array}$ & 03 & -95.9129 & -75.508 \\
\hline 37. & $\begin{array}{l}\text { Tyr220D(2.60) } \\
\text { Tyr220D(3.10) } \\
\text { Glu270E(3.32) } \\
\text { Leu272E(2.84) }\end{array}$ & 04 & -87.1465 & -66.351 \\
\hline 38. & $\begin{array}{l}\text { Asn54A(4.39) } \\
\text { Asn54A(3.07) } \\
\text { Asn54A(2.81) } \\
\text { Asn54A(3.20) } \\
\text { Ser51A(3.01) } \\
\text { Thr58A(3.32) } \\
\text { Thr58A(2.60) } \\
\text { Thr133A(2.60) } \\
\text { Thr133A(3.09) }\end{array}$ & 09 & -66.344 & -56.6716 \\
\hline 39. & $\begin{array}{l}\text { Ser51E(3.48) } \\
\text { Glu52E(3.08) } \\
\text { Val53E(2.73) } \\
\text { Lys274A(3.53) } \\
\text { Lys274A(3.50) } \\
\text { Gln185E(3.11) } \\
\text { Gln185E(2.68) }\end{array}$ & 07 & -77.0854 & -61.0754 \\
\hline 40. & $\begin{array}{l}\text { Glu270E(3.51) } \\
\text { Leu272E(2.61) } \\
\text { Tyr220D(2.89) } \\
\text { Tyr220D(2.62) }\end{array}$ & 04 & -85.5476 & -67.9772 \\
\hline 41. & $\begin{array}{l}\text { Leu272A(3.12) } \\
\text { Glu270A(3.00) } \\
\text { Tyr220E(3.27) } \\
\text { Tyr220E(2.57) }\end{array}$ & 04 & -85.5826 & -67.9772 \\
\hline 42. & $\begin{array}{l}\text { Lys102E(2.60) } \\
\text { Asn54E(2.87) } \\
\text { Asp48D(3.22) }\end{array}$ & 03 & -80.6801 & -68.0583 \\
\hline
\end{tabular}


World Journal of Advanced Research and Reviews, 2020, 08(01), 151-179

\begin{tabular}{|c|c|c|c|c|}
\hline 43. & $\begin{array}{l}\text { Tyr220E(3.11) } \\
\text { Tyr220E(2.60) } \\
\text { Leu272A(2.90) } \\
\text { Glu270A(3.03) }\end{array}$ & 04 & -83.6607 & -64.9301 \\
\hline 44. & $\begin{array}{l}\text { Asn54E(3.23) } \\
\text { Asn54E(2.95) } \\
\text { Asn54E(2.86) } \\
\text { Lys102E(3.23) } \\
\text { Lys102E(3.20) }\end{array}$ & 05 & -112.67 & -90.5476 \\
\hline 45. & $\begin{array}{l}\text { Thr133A(3.04) } \\
\text { Glu52A(2.97) } \\
\text { Glu52A(2.85) } \\
\text { Ser51A(2.81) } \\
\text { Ser51A(3.39) } \\
\text { Val53A(3.25) } \\
\text { Val53A(2.80) } \\
\text { Asn54A(2.59) } \\
\text { Asn54A(2.98) }\end{array}$ & 09 & -89.8604 & -58.2243 \\
\hline 46. & $\begin{array}{l}\text { Asn54A(3.30) } \\
\text { Asn54A(3.10) } \\
\text { Ser51A(3.40) } \\
\text { Lys274B(2.51) } \\
\text { Lys274B(3.15) }\end{array}$ & 05 & -126.132 & -88.5639 \\
\hline 47. & $\begin{array}{l}\text { Thr133A(3.14) } \\
\text { Thr58A(2.96) } \\
\text { Glu52A(2.67) } \\
\text { Glu52A(3.34) } \\
\text { Glu52A(2.62) } \\
\text { Ser51A(3.42) } \\
\text { Ser51A(2.72) } \\
\text { Val53A(3.13) } \\
\text { Val53A(2.87) } \\
\text { Asn54A(2.79) } \\
\text { Asn54A(3.26) }\end{array}$ & 11 & -89.7953 & -63.6423 \\
\hline 48. & $\begin{array}{l}\text { Val53E(3.10) } \\
\text { Glu52E(3.09) } \\
\text { Ser51E(2.77) } \\
\text { Asn54A(2.62) } \\
\text { Asn54A(2.60) } \\
\text { Ser51A(2.88) }\end{array}$ & 06 & -81.9496 & -60.5501 \\
\hline 49. & $\begin{array}{l}\text { Lys274E(3.12) } \\
\text { Lys274E(2.99) }\end{array}$ & 02 & -92.4056 & -65.5496 \\
\hline 50. & $\begin{array}{l}\text { Asn54E(3.31) } \\
\text { Lys102E(2.84) } \\
\text { Lys102E(3.20) }\end{array}$ & 05 & -79.9659 & -61.9243 \\
\hline
\end{tabular}




\begin{tabular}{|c|c|c|c|c|}
\hline & $\begin{array}{l}\text { Lys102E(3.11) } \\
\text { Lys102E(3.02) }\end{array}$ & & & \\
\hline 51. & $\begin{array}{l}\text { Thr133A(2.80) } \\
\text { Lys102A(3.40) } \\
\text { Lys102A(2.95) } \\
\text { Lys102A(3.10) } \\
\text { Lys102A(2.93) }\end{array}$ & 05 & -86.731 & -70.2363 \\
\hline 52. & $\begin{array}{l}\text { Val50E(3.07) } \\
\text { Gln185E(2.60) } \\
\text { Lys274A(2.95) } \\
\text { Lys274A(3.21) } \\
\text { Tyr220E(3.10) }\end{array}$ & 05 & -98.4268 & -79.9425 \\
\hline 53. & $\begin{array}{l}\text { Glu52E(2.15) } \\
\text { His267E(2.10) } \\
\text { Glu270A(1.64) } \\
\text { Glu185E(2.72) } \\
\text { Lys274A(3.19) } \\
\text { Lys274A(2.81) } \\
\text { Tyr220E(3.02) }\end{array}$ & 07 & -104.747 & -83.3799 \\
\hline 54. & $\begin{array}{l}\text { Lys102E(3.11) } \\
\text { Thr133E(3.11) } \\
\text { Thr133E(3.18) } \\
\text { Thr58E(3.10) } \\
\text { Thr58E(2.60) } \\
\text { Asp48E(3.00) } \\
\text { Lys102A(2.62) }\end{array}$ & 07 & -70.8889 & -56.1161 \\
\hline 55. & $\begin{array}{l}\text { Asn54A(2.70) } \\
\text { Val50A(3.42) } \\
\text { Thr133A(2.68) } \\
\text { Thr58A(2.74) } \\
\text { Ser51A(3.00) } \\
\text { Ser51A(3.18) }\end{array}$ & 06 & -78.1562 & -64.365 \\
\hline 56. & $\begin{array}{l}\text { Thr58A(2.60) } \\
\text { Thr58A(2.11) } \\
\text { Thr133A(3.19) } \\
\text { Lys102A(3.41) }\end{array}$ & 04 & -78.8618 & -37.6833 \\
\hline 57. & $\begin{array}{l}\text { Asn54E(3.10) } \\
\text { Thr133E(2.75) } \\
\text { Thr133E(2.71) } \\
\text { Thr58E(3.32) } \\
\text { Thr58E(2.40) }\end{array}$ & 05 & -73.2504 & -61.2585 \\
\hline 58. & $\begin{array}{l}\text { Lys102A(3.15) } \\
\text { Lys102A(2.91) } \\
\text { Thr133A(3.30) } \\
\text { Thr133A(2.67) }\end{array}$ & 06 & -83.8136 & -59.7092 \\
\hline
\end{tabular}


World Journal of Advanced Research and Reviews, 2020, 08(01), 151-179

\begin{tabular}{|c|c|c|c|c|}
\hline & $\begin{array}{l}\text { Thr58A(3.03) } \\
\text { Thr58A(2.62) }\end{array}$ & & & \\
\hline 59. & $\begin{array}{l}\text { Asn54A(3.17) } \\
\text { Asn54A(3.29) } \\
\text { Ser51A(3.03) } \\
\text { Ser51A(2.89) } \\
\text { Thr58A(2.28) } \\
\text { Asp56A(2.93) } \\
\text { Asp56A(2.35) } \\
\text { Glu51A(3.18) }\end{array}$ & 08 & -74.7356 & -46.6527 \\
\hline 60. & $\begin{array}{l}\text { Glu52D(3.27) } \\
\text { Glu52D(2.67) } \\
\text { Val53D(2.69) } \\
\text { Val53D(3.53) } \\
\text { Ser51D(3.15) } \\
\text { Ser51D(2.60) }\end{array}$ & 06 & -80.719 & -67.5649 \\
\hline 61. & $\begin{array}{l}\text { Thr133E(3.15) } \\
\text { Thr133E(3.10) } \\
\text { Thr133E(2.86) } \\
\text { Thr133E(3.38) } \\
\text { Thr58E(3.00) } \\
\text { Lys102A(3.09) } \\
\text { Lys102A(2.60) }\end{array}$ & 07 & -77.2372 & -63.0069 \\
\hline 62. & $\begin{array}{l}\text { Thr58D(3.10) } \\
\text { Thr58D(3.49) } \\
\text { Thr58D(3.30) } \\
\text { Thr133D(3.32) } \\
\text { Thr133D (3.41) } \\
\text { Thr133D(2.59) } \\
\text { Lys102D(2.57) } \\
\text { Lys102D(3.39) } \\
\text { Asn54D(3.50) }\end{array}$ & 09 & -75.3832 & -64.5974 \\
\hline 63. & $\begin{array}{l}\text { Asp56A(2.88) } \\
\text { Ser51A(3.54) } \\
\text { Ser51A(3.49) } \\
\text { Asn54A(2.38) } \\
\text { Asn54A(3.54) } \\
\text { Asn54A(3.03) } \\
\text { Asn54A(3.10) } \\
\text { Lys274D(2.41) } \\
\text { Lys274D }(2.85)\end{array}$ & 09 & -82.2592 & -67.9179 \\
\hline 64. & $\begin{array}{l}\text { Lys274E(3.18) } \\
\text { Asn54E(2.94) } \\
\text { Asn54E(3.56) } \\
\text { Asp56E(3.10) } \\
\text { Lys102E(3.13) }\end{array}$ & 07 & -96.0926 & -79.5424 \\
\hline
\end{tabular}




\begin{tabular}{|l|l|l|l|l|}
\hline & Lys102E(2.78) & & & \\
& Lys102E(2.89) & & -102.653 & -70.907 \\
\hline 65. & Thr133E(2.62) & 11 & & \\
& Thr133E(3.13) & & \\
Lys102A(3.05) & & & \\
& Lys102A(3.19) & & \\
Asn54A(3.10) & & & \\
Asn54A(2.65) & & & \\
& Thr133A(3.35) & & \\
& Thr133A(2.60) & & \\
& Thr58A(2.73) & & & \\
& Thr58A(2.37) & & & \\
& Thr58A(2.25) & & & \\
\hline
\end{tabular}

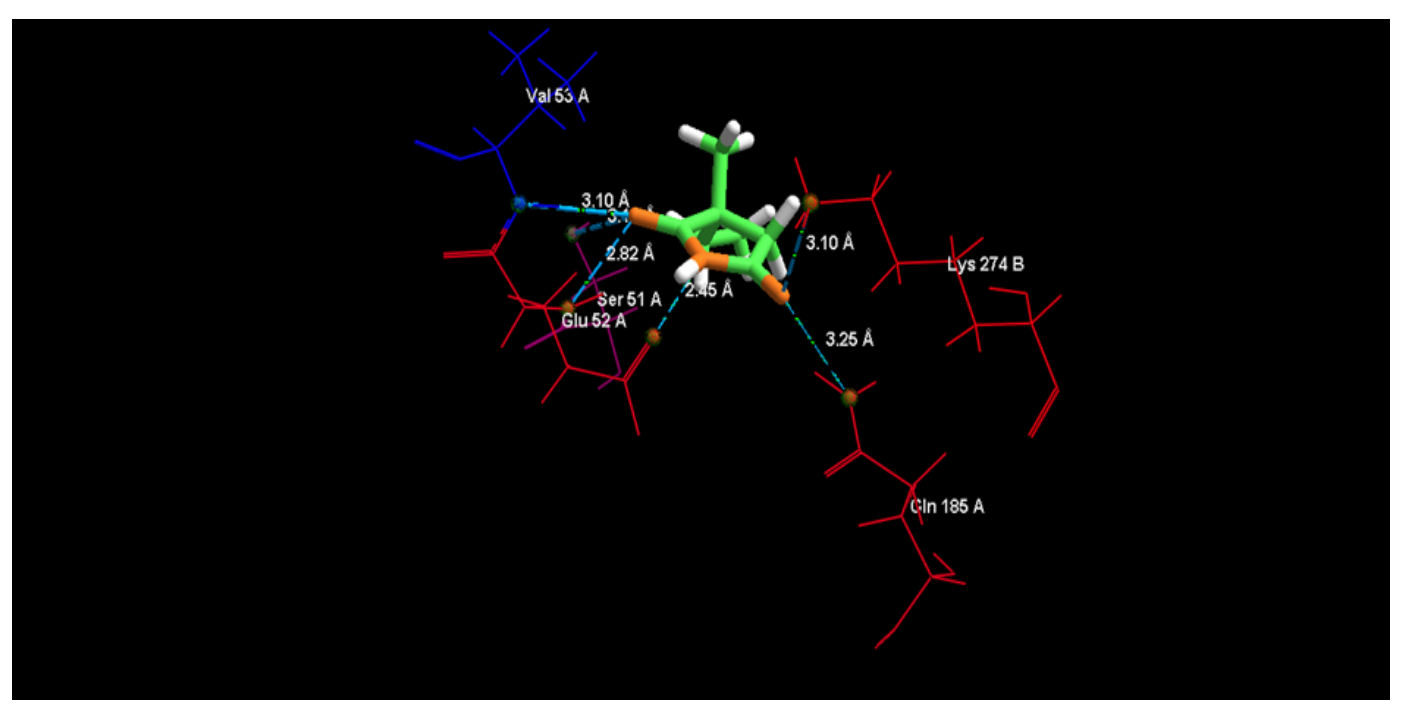

Figure 6 Standard drug Ethosuximide showing of amino acid interaction with bond length Lys274B (3.10); Gln185A (3.25); Ser51A (3.13); Glu52A (2.45); Glu52A (2.82); Val53A (3.10).

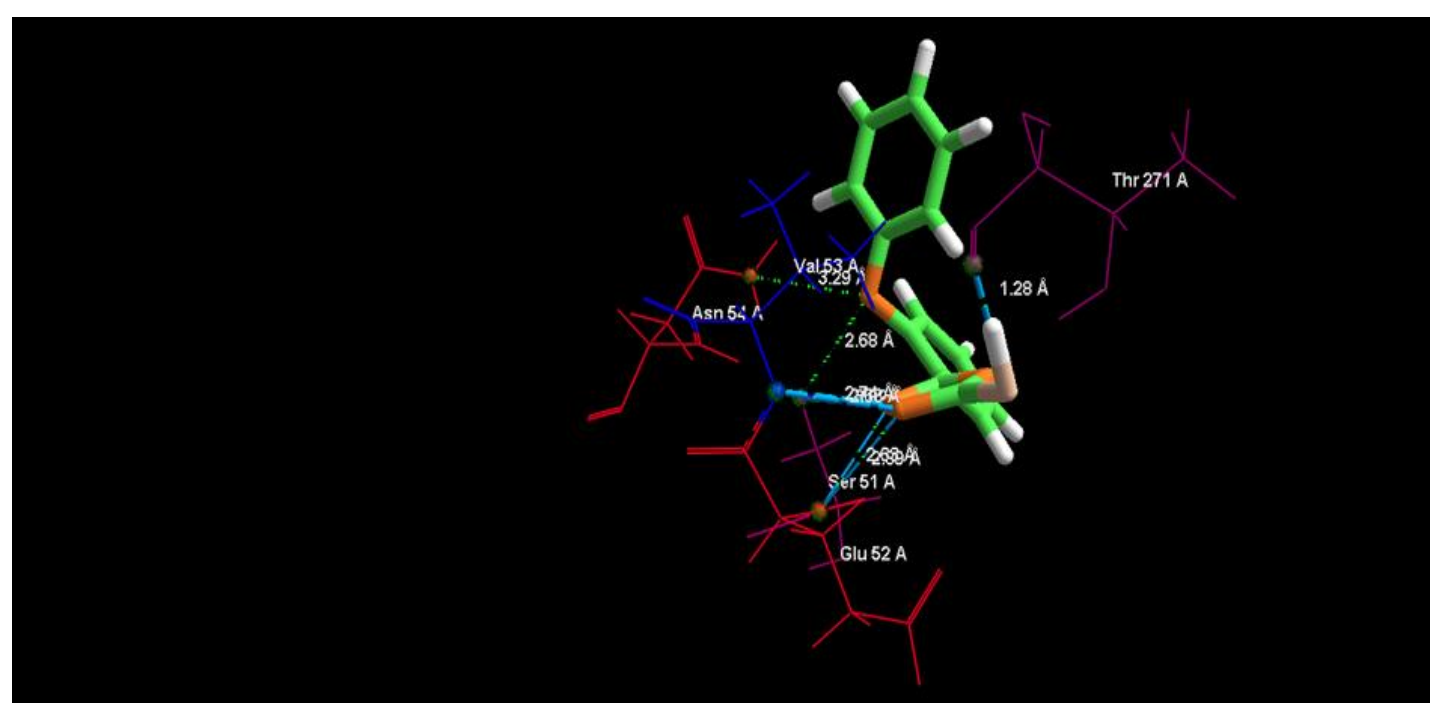

Figure 7 Compound-33 showing interaction of amino acid with bond length Asn54A (3.20); Val53A (2.74); Val53A (2.68); Ser51A (3.02); Ser51A (2.68); Glu52A (2.63); Glu52A (2.89); Thr271A (1.28). 


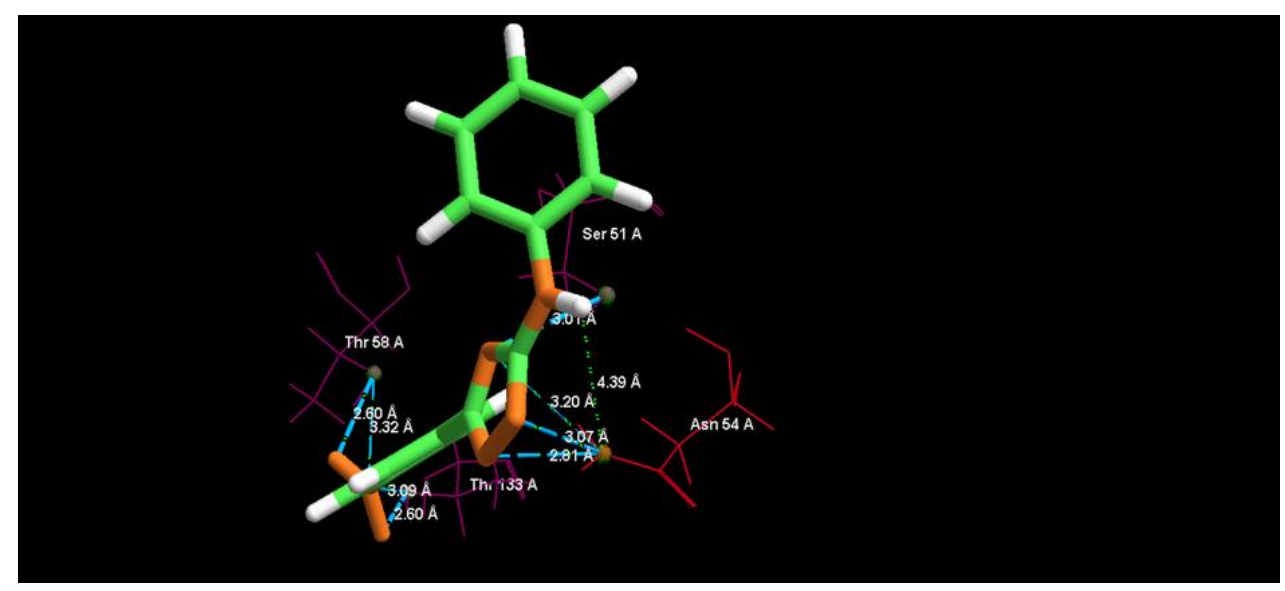

Figure 8 Compound-38 showing interaction of amino acid with bond length Asn54A (4.39); Asn54A (3.07); Asn54A (2.81); Asn54A (3.20); Ser51A (3.01); Thr58A (3.32); Thr58A (2.60); Thr133A (2.60); Thr133A (3.09).

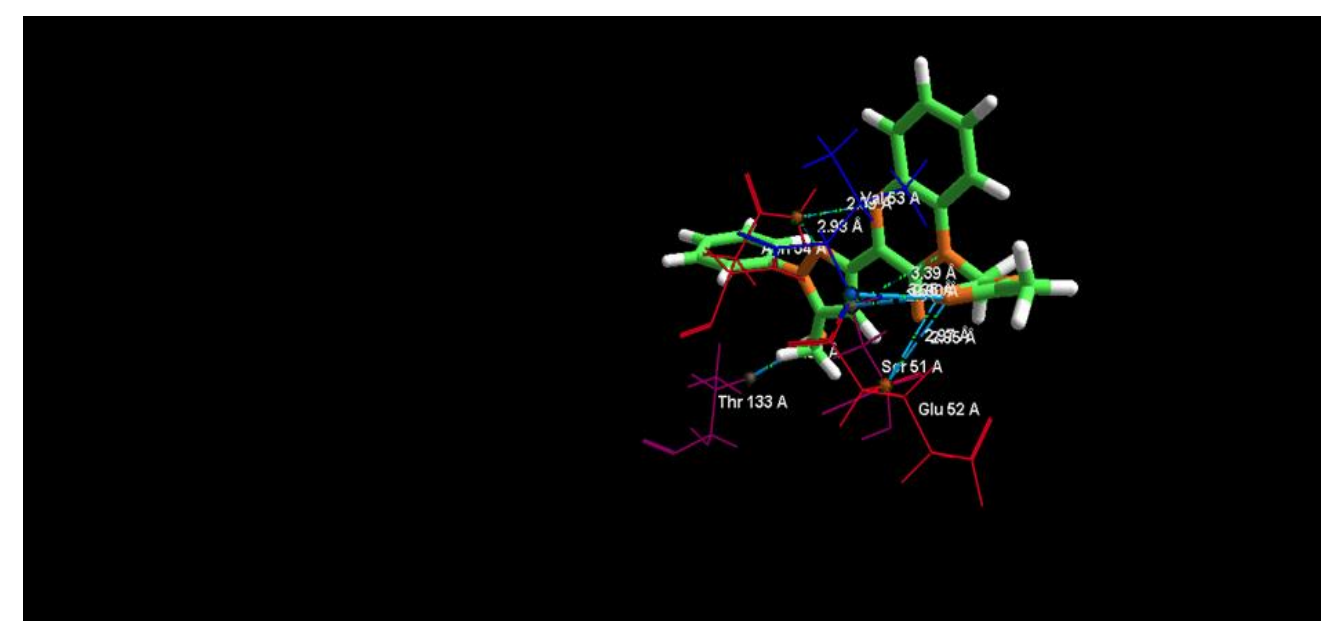

Figure 9 Compound-45 showing interaction of amino acid with bond length Thr133A (3.04); Glu52A (2.97); Glu52A (2.85); Ser51A (2.81); Ser51A (3.39); Val53A (3.25); Val53A (2.80); Asn54A (2.59); Asn54A (2.98).

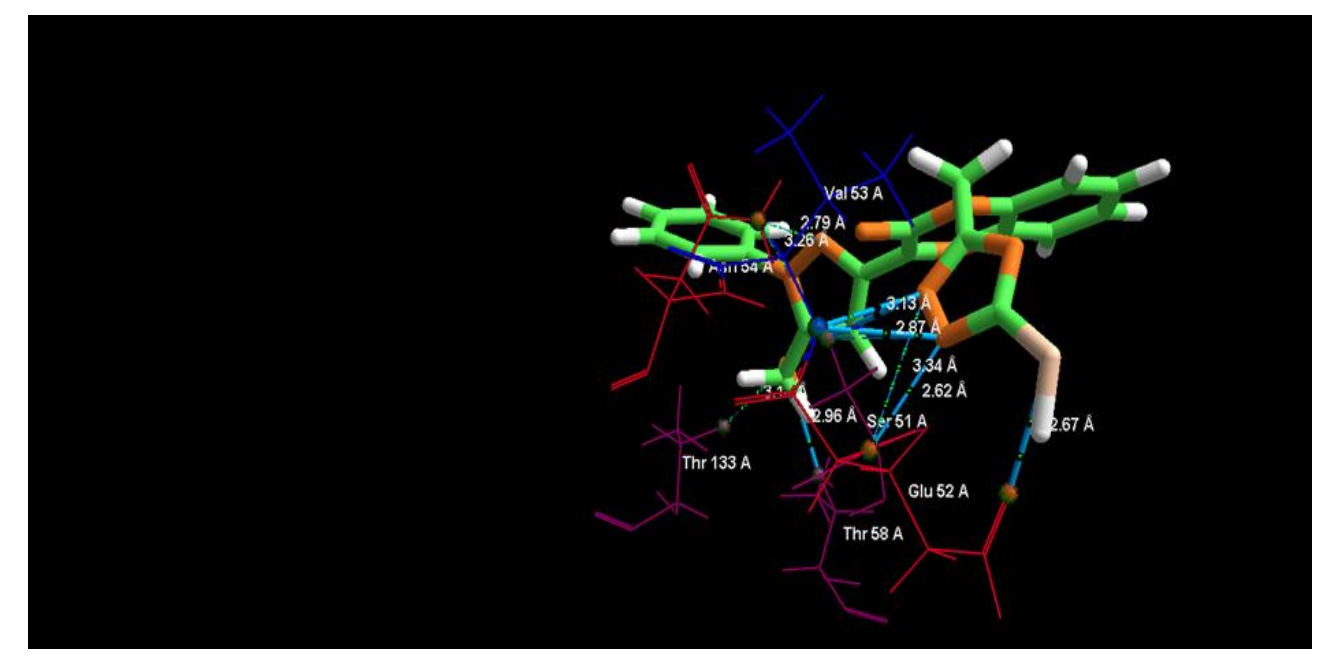

Figure 10 Compound-47 showing interaction of amino acid with bond length Thr133A (3.14); Thr58A (2.96); Glu52A (2.67); Glu52A (3.34); Glu52A (2.62); Ser51A (3.42); Ser51A (2.72); Val53A (3.13); Val53A (2.87); Asn54A (2.79); Asn54A (3.26). 


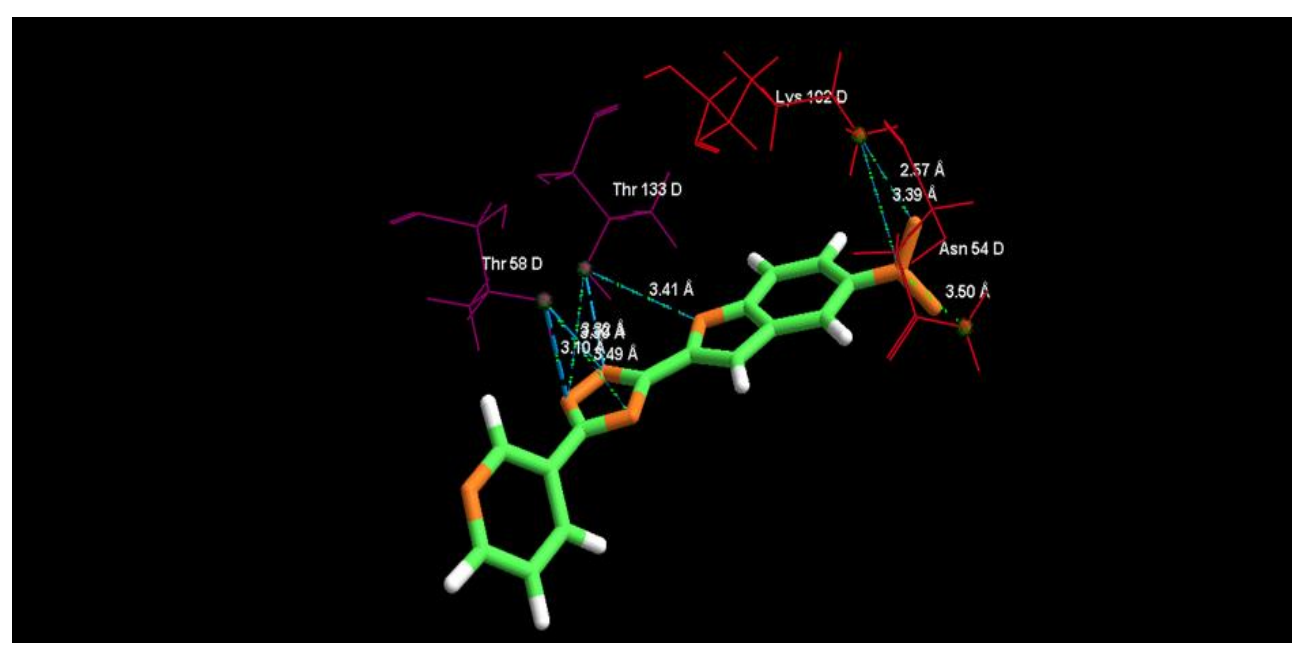

Figure 11 Compound-62 showing interaction of amino acid with bond length Thr58D (3.10); Thr58D (3.49); Thr58D (3.30); Thr133D (3.32); Thr133D (3.41); Thr133D (2.59); Lys102D (2.57); Lys102D (3.39); Asn54D (3.50).

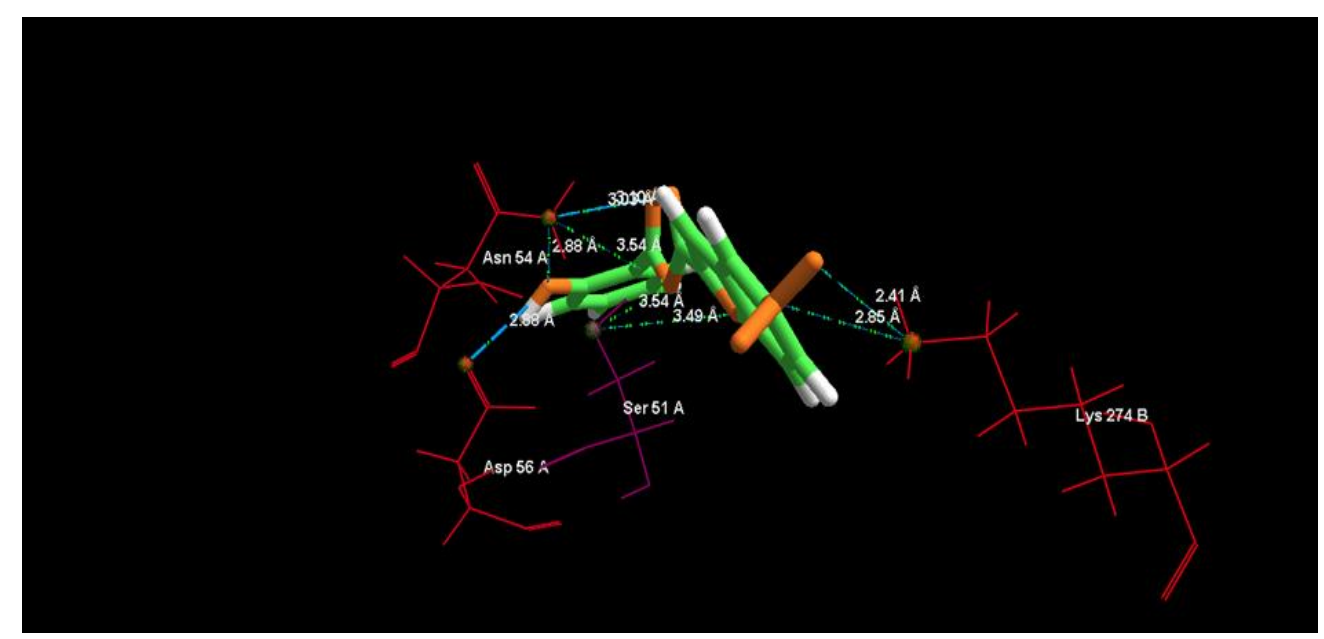

Figure 12 Compound-63 showing interaction of amino acid with bond length Asp56A (2.88); Ser51A (3.54); Ser51A (3.49); Asn54A (2.38); Asn54A (3.54); Asn54A (3.03); Asn54A (3.10); Lys274D (2.41); Lys274D (2.85).

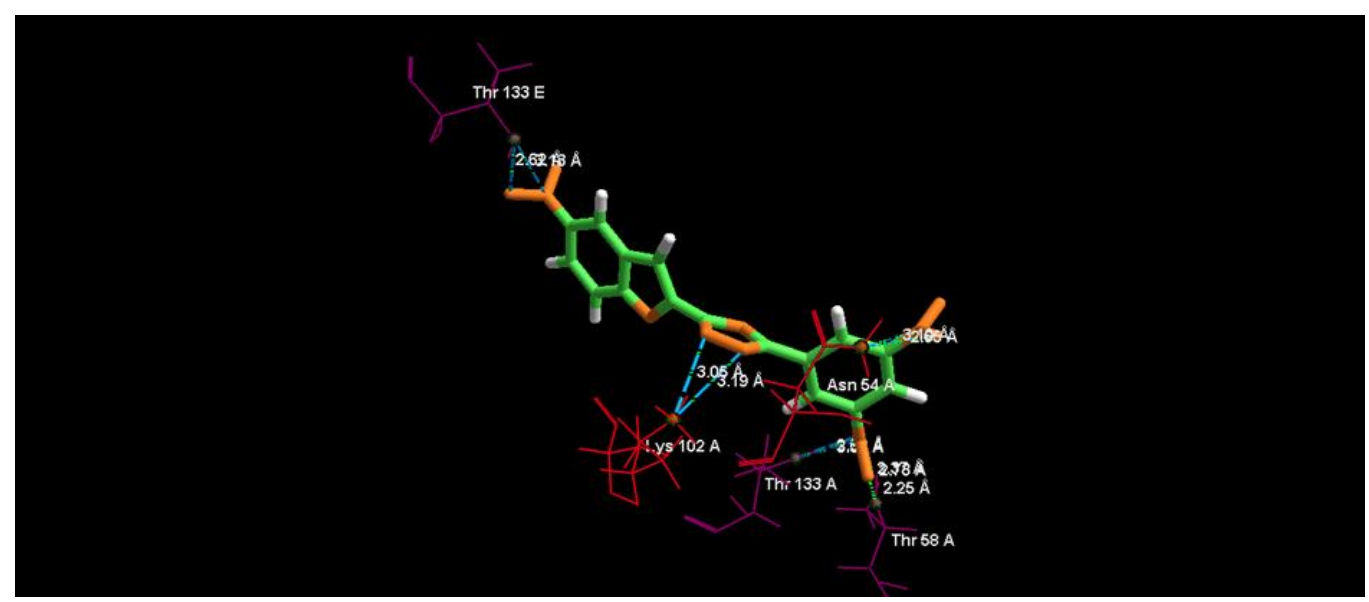

Figure 13 Compound-65 showing interaction of amino acid with bond length Thr133E (2.62); Thr133E (3.13); Lys102A (3.05); Lys102A (3.19); Asn54A (3.10); Asn54A (2.65); Thr133A (3.35); Thr133A (2.60); Thr58A (2.73); Thr58A (2.37); Thr58A (2.25). 


\section{Conclusion}

The obtained results indicated that all studied ligands have similar position and orientation inside the putative binding site of GABAA receptor (PDB code 4COF) which reveals a large space bounded by a membrane-binding domain which serves as an entry channel for substrate to the active site (Fig. 4). In addition, the affinity of any small molecule can be considered as a unique tool in the field of drug design. There is a relationship between the affinity of organic molecules and the free energy of binding. This relationship can contribute in prediction and interpretation of the activity of the organic compounds toward the specific target protein. Moreover, it was additionally tested that geometry of receptor plays necessary role in shaping drug action. Current study provides opportunity for researchers lead for novel acting agents that could be used as new therapeutic options for this brain disorder.

\section{Compliance with ethical standards}

\section{Acknowledgments}

We express our sincere thanks to our guide Dr. Manjusha Choudhary and Director of the Institute of Pharmaceutical Sciences, Kurukshetra University, Kurukshetra for providing necessary research facilities.

\section{Disclosure of conflict of interest}

The authors declare no conflict of interest.

\section{References}

[1] Meng XY, Zhang HX, Mezei M, Cui M. Molecular docking: a powerful approach for structure-based drug discovery. Current computer-aided drug design. 2011; 7(2): 146-57.

[2] Ferreira LG, Dos Santos RN, Oliva G, Andricopulo AD. Molecular docking and structure-based drug design strategies. Molecules. 2015; 20(7): 13384-421.

[3] Kitchen DB, Decornez H, Furr JR, Bajorath J. Docking and scoring in virtual screening for drug discovery: methods and applications. Nature reviews Drug discovery. 2004; 3(11): 935-49.

[4] Agarwal S, Mehrotra R. An overview of molecular docking. JSM Chem. 2016; 4(2): 1024-8.

[5] Lorber DM, Shoichet BK. Flexible ligand docking using conformational ensembles. Protein Science. 1998; 7(4): 938-50.

[6] Kumar S, Madaan R, Bansal G, Jamwal A, Sharma A. Plants and plant products with potential anticonvulsant activity-a review. Pharmacognosy Communications. 2012; 2(1): 3-99.

[7] Tripathi KD. Essentials of medical pharmacology. JP Medical Ltd. 2013; 30.

[8] Maciuk A, Bouchet MJ, Mazars G, Um BH, Anton R. Nootropic (medhya) plants from ayurvedic pharmacopoeia.

[9] WHO. WHO information kit on epilepsy: what you can do. http://www.who.int/mental_health/neurology/epilepsy/information_kit_epilepsy/en/.

[10] Bahou Y, Alzghoul L, Alajloni EM, Albliwi MA, Alsabatin NO, Toubah YK. Knowledge and awareness among patients with epilepsy observed at Jordan University Hospital. Epilepsy \& Behavior. 2020; 102: 106697.

[11] Idrissi AJ, Lamkaddem A, Boujraf S, Souirti Z. Awareness and attitudes toward persons with epilepsy among teachers: A Moroccan study. Epilepsy \& Behavior. 2020; 102: 106633.

[12] Fiest KM, Sauro KM, Wiebe S, Patten SB, Kwon CS, Dykeman J, Pringsheim T, Lorenzetti DL, Jetté N. Prevalence and incidence of epilepsy: a systematic review and meta-analysis of international studies. Neurology. 2017; 88(3): 296-303.

[13] GOODMAN LS, Gilman A. The Pharmacological Basis of Therapeutics. Macmillan Company; 12 th edition pg no. 583-608.

[14] Engelborghs S, D’hooge R, De Deyn PP. Pathophysiology of epilepsy. Acta neurologica belgica. 2000; 100(4): 20113. 
[15] Nevalainen O, Ansakorpi H, Simola M, Raitanen J, Isojärvi J, Artama M, Auvinen A. Epilepsy-related clinical characteristics and mortality: a systematic review and meta-analysis. Neurology. 2014; 83(21): 1968-77.

[16] Granbichler CA, Zimmermann G, Oberaigner W, Kuchukhidze G, Ndayisaba JP, Taylor A, Luef G, Bathke AC, Trinka E. Potential years lost and life expectancy in adults with newly diagnosed epilepsy. Epilepsia. 2017; 58(11): 193945.

[17] Baker GA, Jacoby A, Gorry J, Doughty J, Ellina V, SIGN Group. Quality of life of people with epilepsy in Iran, the Gulf, and Near East. Epilepsia. 2005; 46(1): 132-40.

[18] Bhat MA, Al-Omar MA, Siddiqui N. Synthesis, anticonvulsant and neurotoxicity of some novel 1, 3, 4-oxadiazole derivatives of phthalimide, Der Pharma Chemica. 2010; 2(2): 1-0.

[19] Shin HW, Jewells V, Hadar E, Fisher T, Hinn A. Review of epilepsy-etiology, diagnostic evaluation and treatment. Int J Neurorehabilitation. 2014; 1(130): 2376-0281.

[20] Tripathi A, Misra K. Molecular Docking: A structure-based drug designing approach. JSM Chem. 2017; 5(2): 10427.

[21] Gschwend DA, Good AC, Kuntz ID. Molecular docking towards drug discovery. Journal of Molecular Recognition: An Interdisciplinary Journal. 1996; 9(2): 175-86.

[22] Banerjee AG, Das N, Shengule SA, Srivastava RS, Shrivastava SK. Synthesis, characterization, evaluation and molecular dynamics studies of 5, 6-diphenyl-1, 2, 4-triazin-3 (2H)-one derivatives bearing 5-substituted 1, 3, 4-oxadiazole as potential anti-inflammatory and analgesic agents. European journal of medicinal chemistry. 2015; 28(101): 81-95.

[23] Ahsan MJ, Samy JG, Khalilullah H, Nomani MS, Saraswat P, Gaur R, Singh A. Molecular properties prediction and synthesis of novel 1, 3, 4-oxadiazole analogues as potent antimicrobial and antitubercular agents. Bioorganic \& medicinal chemistry letters. 2011; 21(24): 7246-50.

[24] Aboraia AS, Abdel-Rahman HM, Mahfouz NM, El-Gendy MA. Novel 5-(2-hydroxyphenyl)-3-substituted-2, 3dihydro-1, 3, 4-oxadiazole-2-thione derivatives: Promising anticancer agents. Bioorganic \& medicinal chemistry. 2006; 14(4): 1236-46. 